\section{Ankara Üniversitesi Eğitim Bilimleri Fakültesi Özel Eğitim Dergisi}

2021, 22(4), 921-943
ARAŞTIRMA

Gönderim Tarihi: 25.09.20

Kabul Tarihi: 04.03.21

Erken Görünüm: 23.03.21

\title{
Okul Öncesi Öğretmen Adaylarının Kaynaştırmaya Yönelik Öz-Yeterlik Algılarının İncelenmesi*
}

\author{
Serpil Başpınar (D)1
}

\author{
Nesrin Sönmez ${ }^{(D 2}$
}

\begin{abstract}
$\ddot{O} \mathbf{z}$
Giriş: Gelişim ve öğrenmenin en hızlı olduğu okul öncesi dönemde özel gereksinimli çocukların erken tanılanması ve erken müdahalenin nitelikli bir şekilde yapılarak onların potansiyellerini en üst seviyeye ulaştırmak önemlidir. $\mathrm{Bu}$ dönemde kaynaştırma uygulamalarının niteliği bu uygulamaları yürüten öğretmenlerin yeterlikleriyle birebir ilişkilidir. Bu çalışmanın amacı, okul öncesi öğretmeni adaylarının kaynaştırma konusunda öz-yeterlik algı düzeylerini belirlemek ve adayların kaynaştırma öz-yeterlik algı düzeylerini, en son mezun olunan okul, daha önce özel gereksinimli bireylerle etkileşimde bulunma durumu, etkileşimin süresi ve öğretmenlik uygulaması yaptığı sınıfta özel gereksinimli çocuk bulunma durumu değişkenleri açısından incelemektir.
\end{abstract}

Yöntem: Çalışmada betimsel tarama modeli kullanılmıştır. Çalışma grubunu okul öncesi öğretmenliği bölümünde öğrenim gören 107 son sınıf öğrencisi oluşturmaktadır. Çalışmada veri toplama aracı olarak "Öğretmen Adayı Bilgi Formu" ve "Özel Gereksinimli Çocukların Kaynaştırılmasına Yönelik Öğretmen Yeterliği Ölçeği”" kullanılmıştır. Araştırma verilerinin analizi bir istatistik programı ile yapılmıştır.

Bulgular: Çalışma sonunda elde edilen bulgulara göre; okul öncesi öğretmeni adaylarının kaynaştırmaya yönelik öz-yeterlik algıları orta düzeydedir. Okul öncesi öğretmeni adaylarının öz-yeterlik algılarının ölçeğin genelinde ve alt ölçeklerde incelenen değişkenler açısından anlamlı farklılık göstermediği belirlenmiştir.

Tartışma: Okul öncesi öğretmeni adaylarının kaynaştırmaya yönelik öz-yeterlik algı düzeyinin arzu edilen seviyede olmaması, kaynaştırma ve özel eğitim alanı ile ilgili bilgilerinin ve uygulama deneyimlerinin hizmet öncesinde yeterince sağlanmadığına işaret etmektedir. Bu bilgi ve deneyimler artarsa kaynaştırmaya yönelik özyeterlik algıları da yüksek düzeye ulaşabilir. Öz-yeterlik algısını etkileyen olası faktörlerin belirlenmesi için başka çalışmalara gereksinim olduğu düşünülmektedir. Yapılacak benzer çalışmalarda nitel yöntemin de kullanılması, bu çalışmadakinden farklı değişkenlerin incelenmesi; öğretmen adaylarının genel öğretmenlik öz-yeterlik algıları ile kaynaştırmaya yönelik öz-yeterlik algılarının ilişkisinin incelenmesi öneriler arasında sayılabilir.

Anahtar sözcükler: Okul öncesi eğitimi, öğretmen adayı, kaynaştırma, öz-yeterlik algısı, özel eğitim.

Atıf için: Başpınar, S., \& Sönmez, N. (2021). Okul öncesi öğretmen adaylarının kaynaştırmaya yönelik öz yeterlik algılarının incelenmesi. Ankara Üniversitesi Eğitim Bilimleri Fakültesi Özel Eğitim Dergisi, 22(4), 921943. https://doi.org/10.21565/ozelegitimdergisi.799776

*Bu çalışma, birinci yazarın Akdeniz Üniversitesi Eğitim Bilimleri Enstitüsünde kabul edilmiş yüksek lisans tezinden üretilmiştir

${ }^{1}$ Uzm., Kumluca Sarıcasu Özel Eğitim Meslek Okulu, E-posta: serpilbspnr@gmail.com, https://orcid.org/0000-0002-1622$\underline{117 X}$

${ }^{2}$ Sorumlu Yazar: Dr. Öğr. Üyesi, Akdeniz Üniversitesi, E-posta: ndilersonmez@ gmail.com, https://orcid.org/0000-0002-2497$\underline{2336}$ 


\section{Giriş}

Özel gereksinimli bireyleri topluma kazandırmak amacıyla onların bireysel farklılıklarının en aza indirilmesi ve sahip oldukları zihinsel, fiziksel ve sosyal becerilerini geliştirerek eğitim ihtiyaçlarının karşılanması özel eğitim hizmetleriyle mümkün olabilmektedir (Diken \& Sucuoğlu, 1999). Tarihsel süreç içerisinde insan hakları ve özgürlük hareketinin gelişimine paralel olarak özel eğitim hizmetlerinde değişiklikler olduğu görülmektedir. Her bireyin toplumun bir parçası olduğu; toplumun da aile, okul ve kültürden ayrı düşünülemeyeceği ve bundan dolayı özel gereksinimli bireylerin de akranlarıyla birlikte genel eğitim ortamlarından yararlanma haklarının olduğu fikri zamanla daha fazla kabul görmüş (Kilgo \& Gorgiarla, 2005), bu görüş de kaynaştırma uygulamalarının temelini oluşturmuştur.

“Özel gereksinimli çocukların genel eğitim okullarında normal gelişim gösteren akranlarıyla birlikte, gerektiğinde kendisine ve sınıf öğretmenine destek hizmetler sağlamak suretiyle eğitim görmesi” şeklinde tanımlanan kaynaştırma (Sucuoğlu, 2006), özel gereksinimli bireylerin, toplumun bir üyesi olarak akranları ile eşit eğitim firsatlarından yararlanmaları için zorunludur. Ayrıca kaynaştırmaya olabildiğince erken dönemde başlamak önemlidir. Bunun için en uygun dönem, gelişim ve öğrenmenin en hızlı olduğu okul öncesi dönemdir. Okul öncesi dönemde bilişsel, motor, sosyal ve duygusal gelişim, dil gelişimi ve öz-bakım becerilerinin temelinin atıldığ düşünüldüğünde, bu dönemde alınan eğitimin, gelişimi olağan ilerleyen çocuklar için olduğu kadar özel gereksinimli çocuklar açısından da son derece gerekli ve önemli olduğu ortaya çıkmaktadır (Milli Eğitim Bakanlığı [MEB], 2013). Özel gereksinimli bireyler mümkün olduğunca erken tanılanarak akranlarıyla birlikte eğitim almaya başladıklarında, ilerleyen yıllarda akranlarıyla aralarında oluşması beklenen fark daha az olacağı için okul öncesi eğitimde kaynaştırmanın önemi bir kat daha artmaktadır (Batu, 2010).

Kaynaştırma uygulamalarında, öğretmenin, ailenin, gelişimi olağan seyreden ve özel gereksinimli çocukların kaynaştırma eğitimine yaklaşımları kaynaştırmanın başarısını belirleyen unsurlardır (Batu, 2010; Güleç-Aslan, 2020). Sınıfındaki özel gereksinimli çocuklara nitelikli eğitim vermek öğretmenin temel görev ve sorumlulukları arasındadır. Özel gereksinimli çocukların, sınıfta gereksinimlerinin karşılanması ve sosyal kabulünün sağlanması için öğretmenlerin çaba göstermesi gereklidir (Aydın \& Tuğluk, 2020). Öğretmen, özel gereksinimli çocuğun kaynaştırılmasında, olumlu sınıf ortamı oluşturulmasında ve ailelerin sürece katılmasında birleştirici bir güçtür (Sucuoğlu vd., 2013). Bunun yanı sıra öğretmenlerin kaynaştırma uygulamalarında istekli olmaları ve özel gereksinimli bireyleri kabullenici bir tutum sergilemeleri de kaynaştırma uygulamalarının başarısını olumlu yönde etkilemektedir (Kayhan vd., 2012; Rakap vd., 2017; Seçer vd., 2010). Öğretmenlerin kaynaştırmaya ilişkin görüşleri, kaynaştırma konusunda eğitim almaları ve öğrencileriyle ilişkileri okul öncesi kaynaştırma sınıflarının genel kalitesini yordayan değişkenlerdir (Bakkaloğlu vd., 2019). Dolayısıyla okul öncesi eğitim kurumlarında görev yapan öğretmenlerin kendilerinden beklenen görevleri yerine getirme konusundaki yeterlikleri kaynaştırma uygulamalarının başarısı açısından oldukça önemlidir (Kurniawati vd., 2012; Özdemir \& Ahmetoğlu, 2012).

Alan yazın incelendiğinde, okul öncesi öğretmenlerinin kaynaştırmaya yönelik bilgi düzeylerinin yeterli olmadığı pek çok araştırma bulgusu ile desteklenmektedir (Altun \& Gülben, 2009; Artan \& Uyanık-Balat, 2003; Aydın \& Tuğluk, 2020; Gezer \& Aksoy, 2019; Gök \& Erbaş, 2011; Güleç-Aslan, 2020; Koçyiğit, 2015; KüçükDoğaroğlu \& Bapoğlu-Dümenci, 2015; Özdemir \& Ahmetoğlu, 2012; Sucuoğlu vd., 2013; Yıkmış vd., 2018; Zabeli \& Gjelaj, 2020). Eğitimciler, çocukların yaşadığı problem davranışlara etkin müdahale, bireyselleştirilmiş eğitim programı (BEP) hazırlama, etkinlikleri ve eğitim ortamını uyarlama, yetersizlik türleri ve konularında bilgi eksikliği yaşamaktadır (Çulhaoğlu-İmrak, 2009; Gök \& Erbaş, 2011). Yıkmış ve Bahar (2002) sınıf ve branş öğretmenleri ile yaptıkları çalışmada, kaynaştırma sınıfında görevli eğitimcilerin uzman yardımı olmadan eğitsel hedef saptama, öğretimi düzenleme ve uygulamada kolaylaştırıcı ve destekleyici etkinliklerde bulunmada, özel gereksinimli çocukların, özel gereksinimi olmayan öğrencilerle iletişimini sağlamada, değerlendirme araç gereç ve süreçlerine zaman ayırmada yetersiz kaldıklarını saptamıştır. Sucuoğlu ve Akalın (2010) konu ile ilgili yapılmış araştırmalarda eğitimcilerin sıklıkla, özel gereksinimli çocukların eğitimi için gerekli yöntem ve teknikleri bilmediklerini, sınıf içi etkinliklerde yapılması gereken uyarlamaları yapamadıklarını vurguladıklarını belirtmektedir. Öğretmenlerin kaynaştırma uygulamaları konusunda yeterli olmadıklarına yönelik tüm bu bulgular, hizmet öncesi eğitimlerinde bu konuda nasıl bir eğitim aldıklarını inceleme gereğini doğurmaktadır.

Türkiye'de üniversitelerin okul öncesi öğretmenliği lisans programında zorunlu dersler arasında yalnızca sekizinci yarıyılda iki kredilik teorik bir ders olan "Özel Eğitim ve Kaynaştırma" dersi yer almaktadır (Yükseköğretim Kurulu [YÖK], 2018). 2018 öncesinde uygulanan programda ise zorunlu ders olarak altınc1 yarıyılda yer alan Özel Eğitim dersi yanında sekizinci yarıyılda da seçmeli olarak "Okul Öncesinde Kaynaştırma” 
dersi yer almıştır. Eski ve yeni programda özel gereksinimli çocuklar ile ilgili uygulamalı derslere ise hiç rastlanmamaktadır. Dolayısıyla öğretmenlerin kendilerini özel eğitim alanında yetersiz bulmalarında, özel eğitim ve kaynaştırmaya yönelik son derece az sayıda ders almış olmalarının ve deneyim sahibi olamamalarının önemli bir etken olabileceği düşünülmektedir. Nitekim pek çok araştırmada okul öncesi öğretmenleri lisans eğitimlerinde aldıkları eğitimin yetersiz kaldığını belirtmektedir. Araştırma sonuçları, kaynaştırmanın başarısının en önemli unsurlarından birisi olan öğretmenlerin kaynaştırma uygulamalarında karşılaştığı güçlüklerin hem özel gereksinimli çocukların hem de akranlarının gelişimlerini etkilediğini, aynı zamanda eğitsel uygulamaları aksatabildiğini göstermektedir. Bu durumun da olumsuz tutumları beraberinde getirdiği ve kaynaştırma programlarının nitelikli ve verimli uygulanmasını zorlaştırdığ 1 belirtilmektedir (Diken \& Sucuoğlu, 1999; Gök \& Erbaş, 2011; Orel vd., 2004; Zabeli \& Gjelaj, 2020). Öğretmenlerin yaşadıkları bu güçlükler kaynaştırmaya bakış açılarını olumsuz etkilemekte, çocuklara nasıl bir yaklaşımda bulunup eğitim sürecini nasıl yöneteceklerini bilemedikleri için kendilerini yetersiz hissetmelerine neden olmaktadır (Güleç-Aslan, 2020; Sönmez vd., 2018).

"Bir davranışı meydana getirmek için, bireyin harekete geçip geçmemesine ve engeller karşısında göstermesi gereken çabanın ne kadar olacağına ilişkin kişisel inancı” (Bandura, 1977) olarak tanımlanan özyeterlik algısı, bireylerin duygusal tepkilerini, karşılaştığı problemleri çözme yeteneğini ve düşünme biçimlerini de etkilemektedir. Öz-yeterlik algısı ne kadar yüksek olursa, o kişide o denli o işi yapabileceğine olan inanç ve çaba olur. Öz-yeterlik algısı düşük olan insanlar, karşılaştıkları olay ve durumlara dar bir bakış açısından bakarak problemleri olduğundan daha zor algılamakta ve çözmekte zorlanmaktadırlar. Nitekim, okul öncesi öğretmenlerinin ve öğretmen adaylarının farklı konularda öz-yeterlik algılarını araştıran birçok çalışmada (ör. Chung vd., 2005; Guo vd., 2010; Wax \& Dutton, 1991; Yaşar-Ekici, 2017) yüksek öz-yeterlik algısına sahip okul öncesi öğretmen ve öğretmen adaylarının iletişim, empati, iş birliği ve problem çözme yeteneklerinin yüksek olduğu sonucuna ulaşılmıştır. Araştırmalar yüksek öz-yeterlik algısına sahip öğretmenlerin mesleki tükenmişliklerinin daha az olduğunu, üst düzey bilişsel bilgiye ve aile katılımına yönelik olumlu tutuma sahip olduklarını, çocuk merkezli eğitim anlayışına sahip olduklarını, mesleklerine ve özel gereksinimli çocuklara karşı olumlu tutumları olduğunu göstermektedir.

Genel eğitim öğretmenlerinin kaynaştırmaya yönelik öz-yeterlik algıları ile kaynaştırmaya yönelik tutumları arasında anlamlı bir ilişki olduğu görülmektedir (Dolapçı \& Yıldız-Demirtaş, 2016; Savolainen vd., 2012; Toy \& Duru; 2016). Öğretmenlerin/öğretmen adaylarının özel gereksinimli bireylerle çalışma konusunda öz-yeterlik algıları yükseldikçe kaynaştırmaya yönelik tutumları ya da görüşleri de o oranda olumlu olmaktadır (Diken, 2006; Kiel vd., 2020). Öz-yeterlik alg1 düzeyi düşük olan öğretmenler, yetersizliği olan öğrencilerin kaynaştırma ortamlarında eğitim almaları konusunda olumsuz görüş belirtmektedirler (Soodak \& Podell; 1993). Yüksek öz-yeterliliğe sahip öğretmenlerin, özel eğitim şüphesi duyduğu öğrencisini özel eğitime yönlendirme olasılığı azalmaktadır (Meijer \& Foster, 1988). Kendini yetkin görmeyen öğretmen adaylarının ileride sınıfında kaynaştırma öğrencisi olmasını istemediği belirtilmektedir (Kardeş \& Taşkın, 2020).

Farklı branşlardan öğretmenlerin/öğretmen adaylarının kaynaştırma uygulamalarında öz-yeterlik algılarını inceleyen çalışmalara rastlamak mümkündür (Camadan, 2012; Deniz, 2016; Forlin vd., 2010; Kumcağız vd., 2017; Loreman vd., 2013; Özokçu, 2018a, 2018b; Savolainen, vd., 2012; Toy \& Duru, 2016; Vural-Batık \& Fırıncı-Kodaz, 2018; Yavuz, 2017; Yaylacı \& Aksoy, 2016). Okul öncesi öğretmenlerinin/öğretmen adaylarının kaynaştırmaya yönelik öz-yeterlik algılarını inceleyen araştırmalar incelendiğinde ise öğretmenlerle yürütülen çalışmaların adaylarla yürütülenlere oranla daha fazla sayıda yapıldığı görülmüştür. Okul öncesi öğretmeni adaylarıyla yürütülen ve tek çalışma olan Walls'un (2007) çalışmasında araştırmacı okul öncesi öğretmeni adaylarına uyarladığı bir ölçeği kullanarak aday öğretmenlerin aldığı eğitim programının türüne göre, kaynaştırma eğitimi öz-yeterlik algılarını incelemiştir. Araştırmanın sonuçlarına göre, erken çocukluk genel eğitim programı alan öğretmen adaylarının kaynaştırmaya yönelik öz-yeterliğinin, erken çocukluk özel eğitim programı uygulanan adaylara göre daha düşük olduğu görülmüştür.

Okul öncesi öğretmenlerinin kaynaştırma öz-yeterlik algılarını belirlemeyi amaçlayan çalışmalara bakıldığında yalnızca ulusal alanyazında yapılan çalışmalara rastlanmıştır. Sönmez ve diğerleri (2018) karma yöntemle bir çalışma yürütmüş, çalışmanın nicel boyutunda, Walls’un (2007) öğretmen adaylarına uyguladığ ölçeğin Türkçe uyarlamasını (Sönmez \& Bıçak, 2017) kullanarak okul öncesi eğitim öğretmenlerinin öz-yeterlik algılarının 'yeterli' düzeyde olduğunu belirlemiştir. Ancak aynı araştırmanın nitel boyutunda görüşme yapılan öğretmenler kaynaştırmada yetersiz olduklarını ve hizmet içi eğitime gereksinim duyduklarını ifade etmişlerdir. Çalışkan (2019), okul öncesi öğretmenlerinin kaynaştırmaya yönelik öz-yeterlik algılarını, bu çalışmada kullanılandan farklı olan ve branş ayrımı olmaksızın tüm öğretmenlere uygulanabilen "Kaynaştırmada Öğretmen Yeterliği Ölçeği (KÖYÖ)” ile belirlemiş ve sonuçta öz-yeterlik algılarını ‘yüksek olasılıkla yapabilirim’ düzeyinde 
bulmuştur. Özokçu (2018c), Kaynaştırma Uygulaması için Öğretmen Yeterliği Ölçeği’ni kullandığı çalışmasında, okul öncesi öğretmenlerinin kaynaştırma öz-yeterlik algılarını ‘yüksek olasılıkla yapabilirim' olarak belirlemiştir. Yaman (2019), Battal ve diğerleri (2005) (akt., Yaman, 2019) tarafından geliştirilmiş olan Kaynaştırma Eğitimi Anketi'ni okul öncesi öğretmenlerine uyarlayarak uygulamış ve çalışma sonunda öğretmenlerin kaynaştırma eğitiminde uyguladıkları yöntem ve teknikleri bilme ve kullanabilme yeterlikleri ve kaynaştırma eğitimi ilkelerinin bilinmesi ve uygulayabilme yeterliklerini 'orta' seviyede bulmuştur. Keleş ve diğerleri (2019) ise çalışmalarında okul öncesi eğitiminde kaynaştırma uygulaması yapan öğretmenlerin öz-yeterlik (algı) düzeylerini belirlemek amacıyla kullanılacak bir ölçek geliştirme çalışması yapmışlardır. Çalışmalarında geliştirdikleri Kaynaştırma Sınıfı Öğretmenlerinin Öz-Yeterlik Ölçeği isimli ölçeğin güvenilir ve geçerli bir ölçme aracı olduğunu belirlemişlerdir.

Gelişim ve öğrenmenin en hızlı olduğu okul öncesi dönemde özel gereksinimli çocukların erken tanılanması ve erken müdahalenin nitelikli bir şekilde yapılarak onların potansiyellerini en üst seviyeye çıkarmak için kaynaştırma uygulamaları ve öğretmenlerin kaynaştırmaya yönelik yeterlikleri önemlidir. Araştırma sonuçları, öğretmenlerin öz-yeterlik algı düzeyinin, sınıf içi ve sınıf dışında göstereceği başarıyı doğrudan etkilediğini ve öğrenme-öğretme süreçlerini şekillendirdiğini ortaya koymaktadır. Ayrıca okul öncesi öğretmenlerinin ya da öğretmen adaylarının kaynaştırmaya yönelik öz-yeterliklerini inceleyen çalışmalar az sayıdadır ve bunlar arasında çok sınırlı çalışmada doğrudan okul öncesinde kaynaştırmaya yönelik öz-yeterlik algılarını ölçen ölçekler kullanılmıştır. Yine bu çalışmalar arasında yalnızca bir çalı̧̧mada öğretmen adaylarının kaynaştırma öz-yeterlik algılarının incelendiği görülmüştür. Türkiye'de okul öncesi öğretmeni adaylarının kaynaştırmaya yönelik öz-yeterlik algılarını ölçen bir çalışmaya rastlanmadığı göz önüne alındığında bu çalışmanın alan yazına katkı sağlayacağı düşünülmektedir. Okul öncesi öğretmeni adaylarının hizmet öncesinde aldıkları erken çocukluk özel eğitim programları (Walls, 2007) ve öğretmenlerin hizmet içinde aldıkları eğitimler (Özsırkıntı, 2018; Sönmez vd., 2019) onların kaynaştırma eğitimi öz-yeterlik algılarına olumlu yönde katkı sağlamaktadır. Benzer şekilde çalışmada incelenen özel gereksinimli bireylerle etkileşimde bulunmanın, uygulama sınıfında özel gereksinimli çocuğun olmasının yani öğretmen adaylarının eğitimleri sırasında onlara sağlanan deneyimlerin de öğretmen adaylarının kaynaştırmaya yönelik öz-yeterlik algılarında etki yaratabileceği düşünülmektedir. Öğretmen adaylarının öz-yeterlik algılarının ve bu algıları etkileyen değiş̧kenlerin belirlenmesi yoluyla mevcut öğretmen yetiştirme programlarının öğretmen adaylarını kaynaştırmaya hazırlama düzeyini de belirlemenin mümkün olabileceği ve elde edilen sonuçlara göre programlarda iyileştirici çalışmalar yapılabileceği beklenmektedir. Bu gereksinimden hareketle bu çalışmada, okul öncesi öğretmeni adaylarının kaynaştırma eğitimi konusunda öz-yeterlik algılarını belirlemek ve öğretmen adaylarının öz-yeterlik algı düzeylerini farklı değişkenler açısından incelemek amaçlanmıştır. Bu amaç doğrultusunda aşağıdaki sorulara yanıt aranmıştır:

1. Okul öncesi öğretmeni adaylarının Özel Gereksinimli Çocukların Kaynaştırılmasına Yönelik Öğretmen Yeterliği Ölçeğinin genelinde ve alt boyutlarında kaynaştırma öz-yeterlik algısı ne düzeydedir?

2. Okul öncesi öğretmeni adaylarının Özel Gereksinimli Çocukların Kaynaştırılmasına Yönelik Öğretmen Yeterliği Ölçeği genelinde ve alt boyutlarında kaynaştırma öz-yeterlik algı düzeyleri;

2.1. En son mezun olunan okul,

2.2. Daha önce özel gereksinimli bireylerle etkileşimde bulunma durumu,

2.3. Özel gereksinimli bireylerle etkileşim süresi ve

2.4. Öğretmenlik uygulaması yaptığı sınıfta özel gereksinimli çocuk bulunma durumuna göre farklılaşmakta mıdır?

\section{Yöntem}

\section{Araştırma Modeli}

$\mathrm{Bu}$ araştırma okul öncesi öğretmeni adaylarının kaynaştırma konusunda öz-yeterlik algı düzeylerini belirlemeyi ve öğretmen adaylarının kaynaştırma öz-yeterlik algı düzeylerinin; en son mezun olunan okul, daha önce özel gereksinimli bireylerle etkileşimde bulunma durumu, etkileşimin süresi ve öğretmenlik uygulaması yaptığı sınıfta özel gereksinimli çocuk bulunma durumu değişkenleri açısından incelemeyi amaçlayan betimsel tarama modelinde bir çalışmadır. Betimsel araştırmalar, ele alınan bir durumu olabildiğince dikkatli ve tam bir şekilde tanımlamayı amaçlar. Büyüköztürk vd. (2011, s. 21), betimsel tarama çalışmalarının eğitim alanındaki araştırmalarda, sıklıkla kullanıldığını ifade etmektedir. "Çünkü araştırmacılar bireylerin, grupların ya da (bazen) fiziksel ortamların (okul gibi) özelliklerini (yetenekler, tercihler, davranışlar vb.) özetlerler” (Büyüköztürk vd. 
2011, s. 21). Karasar'a (2006, s. 77) göre, "tarama modelleri, geçmişte ya da halen var olan bir durumu var olduğu sekliyle betimlemeyi amaçlayan araştırma yaklaşımıdır. Araştırmaya konu olan olay, birey ya da nesne, kendi koşulları içinde ve olduğu gibi tanımlanmaya çalışılır. Onları, herhangi bir şekilde değiştirme, etkileme çabası gösterilmez".

\section{Çalışma Grubu}

Araştırmanın çalışma grubunu, 2016-2017 eğitim yılında bir devlet üniversitesinin okul öncesi öğretmenliği bölümünde 4. sınıfta öğrenim gören ve çalışmaya gönüllü olarak katılan 107 okul öncesi öğretmen adayı oluşturmaktadır. Araştırmaya ilişkin çalışma grubunun demografik bilgileri ile ilgili bilgiler tablolaştırılmıştır. Katılımcıların incelenen değişkenlere ilişskin dağılımı Tablo 1'de sunulmuştur.

\section{Tablo 1}

Katılımcıların İncelenen Değişskenlere İlişkin Dă̆ılımı

\begin{tabular}{|c|c|c|c|c|}
\hline Değişken & Özellik & $f$ & $\%$ & Toplam \\
\hline Cinsiyet $^{\mathrm{a}}$ & $\begin{array}{l}\text { Kadin } \\
\text { Erkek }\end{array}$ & $\begin{array}{l}91 \\
16\end{array}$ & $\begin{array}{l}85.0 \\
15.0\end{array}$ & 107 \\
\hline En son mezun olunan okul & $\begin{array}{l}\text { Genel lise } \\
\text { Meslek lisesi } \\
\text { Anadolu lisesi } \\
\text { Anadolu öğretmen lisesi } \\
\text { Önlisans } \\
\text { Lisans } \\
\text { Okul belirtilmemiş }\end{array}$ & $\begin{array}{c}32 \\
13 \\
32 \\
23 \\
5 \\
1 \\
1\end{array}$ & $\begin{array}{c}29.9 \\
12.1 \\
29.9 \\
21.5 \\
4.7 \\
0.9 \\
0.9\end{array}$ & 107 \\
\hline $\begin{array}{l}\text { Lisans eğitiminde özel gereksinimli çocukların eğitimi ile } \\
\text { ilgili alınan dersler }\end{array}$ & Özel eğitim & 107 & 100 & 107 \\
\hline Özel gereksinimli bireylerle etkileşimde bulunma durumu & $\begin{array}{l}\text { Evet } \\
\text { Hayır }\end{array}$ & $\begin{array}{l}63 \\
44\end{array}$ & $\begin{array}{l}58.9 \\
41.1\end{array}$ & 107 \\
\hline Özel gereksinimli bireylerle etkileşim süresi & $\begin{array}{l}4 \text { aydan az } \\
4 \text { ay ya da daha fazla } \\
\text { Süresi belirtilmemiş }\end{array}$ & $\begin{array}{c}41 \\
19 \\
3\end{array}$ & $\begin{array}{c}65.0 \\
30.1 \\
4.7\end{array}$ & 63 \\
\hline $\begin{array}{l}\text { Öğretmenlik uygulaması yaptığı sınıfta özel gereksinimli } \\
\text { çocuk bulunma durumu }\end{array}$ & $\begin{array}{l}\text { Var } \\
\text { Yok }\end{array}$ & $\begin{array}{l}36 \\
71\end{array}$ & $\begin{array}{l}33.6 \\
66.4\end{array}$ & 107 \\
\hline
\end{tabular}

Not: Tabloda yer alan yüzde ve frekans değerleri, veri analizi sırasında uç değerlere sahip olması nedeniyle veri setinden çıkarılmış olan bir katılımcı dahil toplam sayılar üzerinden hesaplanmıştır.

${ }^{a} \mathrm{Bu}$ değişkende elde edilen veriler analiz yapmaya elverişli nitelikte olmadığından bu değişkenler analiz dışında bırakılmıştır.

Tablo 1'e bakıldığında, katılımcıların, \%85'i kadındır. Eşit oranda katılımcıların (\%29.9) düz lise ve Anadolu lisesi mezunu olduğu bunun yanında düşük oranda da olsa ön lisans (\%4.7) ve lisans (\%0.9) mezunu olduğu görülmektedir. Öğretmen adaylarının tümü bilgi formunda özel eğitim alanıyla ilgili olarak özel eğitim dersi almış olduklarını belirtmiş olup başka hiçbir ders almadıkları görülmüştür. Katılımcıların yarıdan fazlası (\%58.9), özel gereksinimli bireylerle etkileşimde bulunduğunu belirtmiştir. Yani kısa süreli de olsa birlikte vakit geçirmiş ya da yakın çevresinde özel gereksinimli birey bulunmakta ve en az bir kez de olsa yakın temas kurmuş̧ur. Etkileşimde bulunduğunu ifade edenlerin $\% 65$ 'inin etkileşim sürelerinin 4 aydan kısa olduğu görülmektedir. Katılımcıların \%66.4'ünün öğretmenlik uygulaması yaptığı sınıfta özel gereksinimli çocuk bulunmadığı görülmektedir.

\section{Veri Toplama Araçları}

Araştırma verileri, araştırmacılar tarafından oluşturulan demografik bilgilerin alınmasına yönelik Öğretmen Adayı Bilgi Formu ve Sönmez ve Bıçak (2017) tarafından Türkçeye uyarlanan "Özel Gereksinimli Çocukların Kaynaştırılmasına Yönelik Öğretmen Yeterliği (ÖGÇKÖY)" ölçeği kullanılarak elde edilmiştir.

\section{Öğretmen Adayı Bilgi Formu}

Öğretmen Adayı Bilgi Formu araştırmaya ilişkin 7 sorudan oluşmaktadır. Katılımcıların cinsiyet, yaş, en son mezun oldukları okul, daha önce özel gereksinimli bireylerle etkileşimde bulunup bulunmadığı ve etkileşimde bulunduysa süresi, öğretmenlik uygulaması yaptığı sınıfta özel gereksinimli çocuk bulunup bulunmadığı, varsa sayısı ve yetersizlik türü, lisans eğitiminde özel gereksinimli çocukların eğitimi ile ilgili aldığı dersler sorulmuştur. 


\section{Özel Gereksinimli Çocukların Kaynaştırılmasına Yönelik Öğretmen Yeterliğ̈i Ölçeği}

Walls (2007) tarafından geliştirilen ve Sönmez ve Bıçak (2017) tarafından Türkçeye uyarlanan ÖGÇKÖY ölçeği 5'li likert tipindedir ve 19 maddeden oluşmaktadır. Ölçekten alınabilecek en düşük puan 19 en yüksek puan ise 95 'tir. Ölçeğin alt boyutları; (1) özel eğitimle ilgili yasa ve süreçlere yönelik bilgi, (2) özel gereksinimli çocuklara yönelik bilgi, (3) özel gereksinimli çocuklara öğretim sunma konusunda güven ve (4) etkili öğretim yöntemlerini kullanma ve uyarlama yapmadır. Ölçekte yer alan tüm maddelere ilişkin Cronbach $\alpha$ iç tutarlık katsayısı .96, iki yarı test güvenirlik katsayısı ise .86 'dır. Ölçeğin alt boyutlarına ilişkin Cronbach $\alpha$ iç tutarlık katsayıları sırasıyla; yasa boyutu .856 , bilgi boyutu .966 , kendine güven boyutu .943 , algı boyutu .952 olarak hesaplanmıştır (Sönmez ve Bıçak, 2017). Bu çalışmada ölçeğin öğretmen adaylarına uygulanmasıyla elde edilen verilerde; ölçeğin tamamına ait Cronbach $\alpha$ iç tutarlık katsayısı .924, ölçeğin alt boyutlarına ilişkin Cronbach $\alpha$ iç tutarlık katsayıları sırasılya; yasa boyutunda .704 , bilgi boyutunda .922 , kendine güven boyutunda .827 , alg1 boyutunda .840 olarak hesaplanmıştır. Ölçekten elde edilen Cronbach $\alpha$ değerlerinin .7'den büyük olmas1 nedeniyle (George \& Mallery, 2003) ölçeğin güvenilirliği iyi düzeydedir.

\section{Veri Toplama ve Analizi}

Araştırma verileri 2016-2017 eğitim öğretim yılı bahar yarıyılında toplanmıştır. Verilerin toplandığ dönemde etik kurul kararı, eğitim bilimlerinde yapılan çalışmalarda zorunlu olmaması nedeniyle alınmamış̧ır. Ancak araştırmacı verileri toplanması sırasında hiçbir etik kuralı ihlal etmemeye özen göstermiş, çalışmanın amacını, ölçme aracını ve ölçme yöntemini açıklamak üzere okul öncesi öğretmenliği 4. sınıf öğrencileri ile bir görüşme gerçekleştirilmiştir. Araştırmaya katılmaya gönüllü olan öğrencilerle eğitim fakültesinde bir derslikte önceden belirlenen gün ve saatte bir araya gelinmiştir. Katılımcılara araştırma hakkında detaylı bilgilendirme yapılmış, formlara herhangi bir kimlik bilgisi yazılmaması özellikle belirtilmiştir. Çalışmanın raporlanması sürecinde katılımcılara ait hiçbir bilginin üçüncü şahıslarla paylaşılmayacağı beyan edilmiş̧ir. Çalışmada ayrıca samimi ve eksiksiz şekilde formları doldurmaları konusunda bilgilendirme yapılmıştır.

Çalışmada elde edilen verilerin analizinde istatistiksel analiz programı SPSS 13.0'dan yararlanılmıştır. Veri analizine başlamadan önce, veri setinde yer alan uç değerler incelenmiştir ve bir katılımcı veri setinden çıkarılmıştır. Bu nedenle 106 katılımcıya ait veriler üzerinden analizler yapılııştır. Araştırmada, ölçek genelinden alınan toplam puanların ve ölçeğin her bir alt boyutundan alınan toplam puanların, en son mezun olunan okul, daha önce özel gereksinimli bireylerle etkileşimde bulunma durumu, özel gereksinimli bireylerle etkileşimin süresi, sınıfında özel gereksinimli çocuk bulunma durumu değişkenlerine göre farklılaşıp farklılaşmadığı incelenmiştir. Araştırmanın alt amaçlarına yanıt aramak için, analiz yapılan değişkenin iki alt grubu olduğu durumlarda farkın manidarlı̆̆ının test edilmesinde parametrik teknik olan ilişkisiz örneklemler $t$ testi ya da bunun parametrik olmayan karşllığı olan Mann Whitney U Testi, ikiden fazla alt grubu olduğu durumlarda farkın manidarlığının test edilmesinde parametrik teknik olan ilişkisiz örneklemler için ANOVA ya da bunun parametrik olmayan karşıllı̆̆ olan Kruskal Wallis H-Testi kullanılmıştır.

\section{Bulgular}

Çalışmada ilk olarak okul öncesi öğretmeni adaylarının kaynaştırma öz-yeterlik algılarının düzeyi incelenmiştir. Okul öncesi öğretmeni adaylarının ölçekten ve ölçeğin alt boyutlarından aldıkları puanlara ilişkin betimsel istatistikler Tablo 2'de sunulmuştur.

Tablo 2

Ölçekten Alınan Ortalama Puana Göre Öğretmen Adaylarının Öz-Yeterlik Algı Düzeyi

\begin{tabular}{lcccc}
\hline \multicolumn{1}{c}{ Alt boyut } & Ortalama & SS & Min. & Maks. \\
\hline Özel eğitimle ilgili yasa ve süreçlere yönelik bilgi & 13.77 & 2.52 & 8.00 & 20.00 \\
Özel gereksinimli çocuklara yönelik bilgi & 19.49 & 3.36 & 10.00 & 25.00 \\
Özel gereksinimli çocuklara öğretim sunma konusunda güven & 20.14 & 3.67 & 12.00 & 30.00 \\
Etkili öğretim yöntemlerini kullanma ve uyarlama yapma becerisine yönelik alg1 & 13.83 & 2.75 & 6.00 & 20.00 \\
Toplam & 67.00 & 10.21 & 40.00 & 93.00 \\
\hline
\end{tabular}

Tablo 2 incelendiğinde; araştırmaya katılan 107 öğretmen adayının öz-yeterlik algı test puanının aritmetik ortalamasının 67.00 olduğu görülmektedir. En küçük değeri (minimum) 40.00; en büyük değeri (maksimum) 93.00'tür. 
Özel gereksinimli çocukların kaynaştırılmasına yönelik öğretmen yeterliği ölçeğinden alınan puanlar, uç değerlere sahip bir katılımcıya ait veriler çıkarıldıktan sonra, 106 kişinin $z$ puanları hesaplanıp üç gruba ayrılmasıyla elde edilen grup ortalamaları ve standart sapmaları ile bu grupta yer alan kişilerin aldığı en düşük ve en yüksek puanlar Tablo 3 'te sunulmuştur.

\section{Tablo 3}

Grup Betimsel Istatistikleri

\begin{tabular}{cccccccc}
\hline$Z$ puan1 & Düzey & $f$ & $\%$ & $\bar{X}$ & $S$ & Min. & Maks. \\
\hline$-2.60 /-0.48$ & Alt & 35 & 33.00 & 55.71 & 5.58 & 40 & 62 \\
$-0.39 /-0.57$ & Orta & 36 & 34.00 & 68.03 & 2.56 & 63 & 73 \\
$0.5 /-2.50$ & Üst & 35 & 33.00 & 77.94 & 5.38 & 73 & 93 \\
\hline
\end{tabular}

Tablo 3'e göre ölçekten alınan ortalama puanla (67.00) birlikte değerlendirildiğinde, okul öncesi öğretmeni adaylarının kaynaştırmaya yönelik öz-yeterlik algılarının orta düzeyde olduğu söylenebilir.

Araştırmada ikinci olarak öğretmen adaylarının kaynaştırmaya yönelik öz-yeterlik algılarının; en son mezun olunan okul, daha önce özel gereksinimli bireylerle etkileşimde bulunma durumu, özel gereksinimli bireylerle etkileşimin süresi ve sınıfinda özel gereksinimli çocuk bulunma durumu açısından farklılaşıp farklılaşmadığı incelenmiştir. Öğretmen adaylarının kaynaştırmaya yönelik öz-yeterlik algılarına ilişkin elde edilen bulgular bağımsız değişkenlerin sırasına göre verilmiştir.

\section{En Son Mezun Olunan Okul}

Öğretmen adaylarının kaynaştırmaya yönelik öz-yeterlik algılarının 'en son mezun olunan okul' açısından farklılaşıp farklılaşmadığının belirlenmesi amacıyla yapılan Kruskal Wallis H-Testi sonuçları Tablo 4'te verilmektedir.

\section{Tablo 4}

Öğretmen Adaylarının Kaynaştırmaya Yönelik Öz-Yeterlik Algılarının En Son Mezun Olunan Okul Açısından Kruskal Wallis H-Testi Sonuçları

\begin{tabular}{|c|c|c|c|c|c|c|}
\hline Boyut & Mezun olunan okul & $N$ & Sira ort. & $H$ & $s d$ & $p$ \\
\hline Özel eğitimle ilgili yasa ve süreçlere yönelik bilgi & $\begin{array}{c}\text { Düz lise } \\
\text { Meslek lisesi } \\
\text { Anadolu lisesi } \\
\text { Anadolu öğretmen lisesi } \\
\text { Toplam }^{\mathrm{a}}\end{array}$ & $\begin{array}{l}31 \\
13 \\
32 \\
23 \\
99\end{array}$ & $\begin{array}{l}50.11 \\
52.69 \\
48.30 \\
50.70\end{array}$ & .24 & 3 & .97 \\
\hline Özel gereksinimli çocuklara yönelik bilgi & $\begin{array}{c}\text { Düz lise } \\
\text { Meslek lisesi } \\
\text { Anadolu lisesi } \\
\text { Anadolu öğretmen lisesi } \\
\text { Toplam }^{\mathrm{a}}\end{array}$ & $\begin{array}{l}31 \\
13 \\
32 \\
23 \\
99\end{array}$ & $\begin{array}{l}45.34 \\
58.58 \\
51.27 \\
49.67\end{array}$ & 2.13 & 3 & .55 \\
\hline $\begin{array}{l}\text { Özel gereksinimli çocuklara öğretim sunma } \\
\text { konusundaki güven }\end{array}$ & $\begin{array}{c}\text { Düz lise } \\
\text { Meslek lisesi } \\
\text { Anadolu lisesi } \\
\text { Anadolu öğretmen lisesi } \\
\text { Toplam }^{\mathrm{a}}\end{array}$ & $\begin{array}{l}31 \\
13 \\
32 \\
23 \\
99\end{array}$ & $\begin{array}{l}46.55 \\
55.15 \\
52.92 \\
47.67\end{array}$ & 1.36 & 3 & .72 \\
\hline $\begin{array}{l}\text { Etkili öğretim yöntemlerini kullanma ve uyarlama } \\
\text { yapma becerisine yönelik alg1 }\end{array}$ & $\begin{array}{c}\text { Düz lise } \\
\text { Meslek lisesi } \\
\text { Anadolu lisesi } \\
\text { Anadolu öğretmen lisesi } \\
\text { Toplam }^{\mathrm{a}}\end{array}$ & $\begin{array}{l}31 \\
13 \\
32 \\
23 \\
99\end{array}$ & $\begin{array}{l}46.11 \\
54.08 \\
53.61 \\
47.91\end{array}$ & 1.48 & 3 & .69 \\
\hline Genel & $\begin{array}{c}\text { Düz lise } \\
\text { Meslek lisesi } \\
\text { Anadolu lisesi } \\
\text { Anadolu öğretmen lisesi } \\
\text { Toplam } \\
\text { Tom }\end{array}$ & $\begin{array}{l}31 \\
13 \\
32 \\
23 \\
99\end{array}$ & $\begin{array}{l}46.48 \\
57.50 \\
52.27 \\
47.35\end{array}$ & 1.75 & 3 & .63 \\
\hline
\end{tabular}

${ }^{\mathrm{a}}$ Mezuniyet bilgilerini dolduran katılımcılar. 
Tablo 4'te görüldüğü gibi öğretmen adaylarının, Özel Eğitimle İlgili Yasa ve Süreçlere Yönelik Bilgi $(H(3)=.245, p>.05)$, Özel Gereksinimli Çocuklara Yönelik Bilgi $(H(3)=2.134, p>.05)$, Özel Gereksinimli Çocuklara Öğretim Sunma Konusundaki Güven $(H(3)=1.359, p>.05)$ ve Etkili Öğretim Yöntemlerini Kullanma ve Uyarlama Yapma Becerisine Yönelik Alg1 $(H(3)=1.482, p>.05)$ puanlarının, en son mezun olunan okul açısından anlamlı farklılık göstermediği görülmektedir. Tablo 4'te görüldüğü gibi öğretmen adaylarının kaynaştırma öz-yeterlik algıları ölçek genelinde de anlamlı farklılık oluşturmamıştır $(H(3)=1.750, p>.05)$.

\section{Daha Önce Özel Gereksinimli Bireylerle Etkileşimde Bulunma Durumu}

Öğretmen adaylarının özel gereksinimli bireylerle etkileşimde bulunup bulunmadığ yani kısa süreli de olsa birlikte vakit geçirmiş ya da yakın çevresinde olup en az bir kez de olsa yakın temas kurmuş olup olmadığı açısından kaynaştırmaya yönelik öz-yeterlik algıları incelenmiştir. Öğretmen adaylarının 'daha önce özel gereksinimli bireylerle etkileşimde bulunma durumu' açısından öz-yeterlik algılarının farklılaşıp farklılaşmadığını test etmek amacıyla yapılan ilişkisiz örneklemler t testi sonuçları Tablo 5'te verilmektedir.

\section{Tablo 5}

Öğretmen Adaylarının Kaynaştırmaya Yönelik Öz-Yeterlik Algılarının Daha Önce Özel Gereksinimli Bireylerle Etkileşimde Bulunma Durumu Açısından t Testi Sonuçları

\begin{tabular}{|c|c|c|c|c|c|c|c|}
\hline Boyut & Etkileşim & $N$ & $\bar{X}$ & $S S$ & $t$ & $s d$ & $p$ \\
\hline Özel eğitimle ilgili yasa ve süreçlere yönelik bilgi & $\begin{array}{c}\text { Evet } \\
\text { Hayır } \\
\text { Toplam }\end{array}$ & $\begin{array}{c}63 \\
43 \\
106\end{array}$ & $\begin{array}{l}14.03 \\
13.40\end{array}$ & $\begin{array}{l}2.57 \\
2.43\end{array}$ & 1.28 & 104 & .20 \\
\hline Özel gereksinimli çocuklara yönelik bilgi & $\begin{array}{c}\text { Evet } \\
\text { Hayır } \\
\text { Toplam }\end{array}$ & $\begin{array}{c}63 \\
43 \\
106\end{array}$ & $\begin{array}{l}19.54 \\
19.42\end{array}$ & $\begin{array}{l}3.28 \\
3.53\end{array}$ & .18 & 104 & .86 \\
\hline $\begin{array}{crcc}\text { Özel gereksinimli } & \text { çocuklara öğretim } & \text { sunma } \\
\text { konusundaki güven } & & & \end{array}$ & $\begin{array}{c}\text { Evet } \\
\text { Hayır } \\
\text { Toplam }\end{array}$ & $\begin{array}{c}63 \\
43 \\
106\end{array}$ & $\begin{array}{l}20.48 \\
19.65\end{array}$ & $\begin{array}{l}3.81 \\
3.44\end{array}$ & 1.14 & 104 & .26 \\
\hline $\begin{array}{l}\text { Etkili öğretim yöntemlerini kullanma ve uyarlama } \\
\text { yapma becerisine yönelik algı }\end{array}$ & $\begin{array}{c}\text { Evet } \\
\text { Hayır } \\
\text { Toplam }\end{array}$ & $\begin{array}{c}63 \\
43 \\
106\end{array}$ & $\begin{array}{l}13.97 \\
13.63\end{array}$ & $\begin{array}{l}3.01 \\
2.35\end{array}$ & .62 & 104 & .54 \\
\hline Genel & $\begin{array}{c}\text { Evet } \\
\text { Hayır } \\
\text { Toplam }\end{array}$ & $\begin{array}{c}63 \\
43 \\
106 \\
\end{array}$ & $\begin{array}{l}68.02 \\
66.09\end{array}$ & $\begin{array}{l}10.52 \\
9.76\end{array}$ & .95 & 104 & .34 \\
\hline
\end{tabular}

Tablo 5 incelendiğinde, öğretmen adaylarının Özel Eğitimle İlgili Yasa ve Süreçlere Yönelik Bilgi $(t(104)$ $=1.279, p>.05)$, Özel Gereksinimli Çocuklara Yönelik Bilgi $(t(104)=.181, p>.05)$, Özel Gereksinimli Çocuklara Öğretim Sunma Konusundaki Güven $(t(104)=1.139, p>.05)$ ve Etkili Öğretim Yöntemlerini Kullanma ve Uyarlama Yapma Becerisine Yönelik Algı $(t(104)=.623, p>.05)$ alt boyutlarında öz-yeterlik algılarının, daha önce özel gereksinimli bireylerle etkileşimde bulunma durumu açısından anlamlı farklılık göstermediği görülmektedir. Tablo 5'te görüldüğü gibi öğretmen adaylarının kaynaştırma eğitimi öz-yeterlik algıları daha önce özel gereksinimli bireylerle etkileşimde bulunma durumu açısından ölçek genelinde de anlamlı farklılık oluşturmamıştır $(t(104)=.951, p>.05)$.

\section{Özel Gereksinimli Bireylerle Etkileşimin Süresi}

Öğretmen adaylarının kaynaştırmaya yönelik öz-yeterlik algılarının, özel gereksinimli bireylerle etkileşimde bulunma süreleri açısından farklılaşıp farklılaşmadığını test etmek amacıyla yapılan Mann Whitney U Testi sonuçları Tablo 6'da verilmektedir. 
Tablo 6

Öğretmen Adaylarının Kaynaştırmaya Yönelik Öz-Yeterlik Algllarının Özel Gereksinimli Bireylerle Etkileşimin Süresine Göre Mann Whitney U Testi Sonucu

\begin{tabular}{|c|c|c|c|c|c|c|}
\hline Boyut & Etkileşim süresi & $N$ & Sira ort. & Sira top. & $U$ & $p$ \\
\hline \multirow{3}{*}{ Özel eğitimle ilgili yasa ve süreçlere yönelik bilgi } & 4 aydan az & 41 & 30.00 & 1230.00 & 369.00 & .74 \\
\hline & 4 ay ve daha fazla & 19 & 31.58 & 600.00 & & \\
\hline & Toplam & 60 & & & & \\
\hline \multirow{3}{*}{ Özel gereksinimli çocuklara yönelik bilgi } & 4 aydan az & 41 & 28.91 & 1185.50 & \multirow[t]{3}{*}{324.50} & \multirow[t]{3}{*}{.29} \\
\hline & 4 ay ve daha fazla & 19 & 33.92 & 644.50 & & \\
\hline & Toplam & 60 & & & & \\
\hline \multirow{3}{*}{$\begin{array}{l}\text { Özel gereksinimli çocuklara öğretim sunma } \\
\text { konusundaki güven }\end{array}$} & 4 aydan az & 41 & 29.46 & 1208.00 & \multirow[t]{3}{*}{347.00} & \multirow[t]{3}{*}{.50} \\
\hline & 4 ay ve daha fazla & 19 & 32.74 & 622.00 & & \\
\hline & Toplam & 60 & & & & \\
\hline \multirow{3}{*}{$\begin{array}{l}\text { Etkili öğretim yöntemlerini kullanma ve uyarlama } \\
\text { yapma becerisine yönelik alg1 }\end{array}$} & 4 aydan az & 41 & 29.60 & 1213.50 & \multirow[t]{3}{*}{352.50} & \multirow[t]{3}{*}{.55} \\
\hline & 4 ay ve daha fazla & 19 & 32.45 & 616.50 & & \\
\hline & Toplam & 60 & & & & \\
\hline \multirow{3}{*}{ Genel } & 4 aydan az & 41 & 29.27 & 1200.00 & \multirow[t]{3}{*}{339.00} & \multirow[t]{3}{*}{.42} \\
\hline & 4 ay ve daha fazla & 19 & 33.16 & 630.00 & & \\
\hline & Toplam & 60 & & & & \\
\hline
\end{tabular}

Tablo 6’ya göre, öğretmen adaylarının kaynaştırmaya yönelik öz-yeterlik algılarında, ölçeğin Özel Eğitimle İlgili Yasa ve Süreçlere Yönelik Bilgi $(U=369.00, p>.05)$, Özel Gereksinimli Çocuklara Yönelik Bilgi $(U=324.50, p>.05)$, Özel Gereksinimli Çocuklara Öğretim Sunma Konusundaki Güven $(U=347.00, p>.05)$ ve Etkili Öğretim Yöntemlerini Kullanma ve Uyarlama Yapma Becerisine Yönelik $\operatorname{Alg1}(U=352.50, p>.05)$ alt boyutlarında ve ölçeğin genelinde $(U=475.00, p>.05)$ özel gereksinimli bireylerle etkileşimin süresi açısından anlamlı farklılık bulunmamıştır.

\section{Sınıfında Özel Gereksinimli Çocuk Bulunma Durumu}

Öğretmen adaylarının kaynaştırma eğitimi öz-yeterlik algılarının, sınıfında özel gereksinimli çocuk bulunma durumu açısından farklılaşıp farklılaşmadığını test etmek amacıyla yapılan ilişkisiz örneklemler $t$ testi sonuçları Tablo 7'de verilmektedir.

\section{Tablo 7}

Ögretmen Adaylarının Kaynaştırmaya Yönelik Öz-Yeterlik Algllarının Sınıfında Özel Gereksinimli Çocuk Bulunma Durumuna Göre t Testi Sonucu

\begin{tabular}{|c|c|c|c|c|c|c|c|}
\hline Boyut & Özel gereksinimli çocuk & $N$ & $\bar{X}$ & $S S$ & $t$ & sd & $p$ \\
\hline \multirow{3}{*}{$\begin{array}{l}\text { Özel eğitimle ilgili yasa ve süreçlere } \\
\text { yönelik bilgi }\end{array}$} & Var & 36 & 14.11 & 2.82 & & & \\
\hline & Yok & 70 & 13.60 & 2.36 & .99 & 104 & .33 \\
\hline & Toplam & 106 & & & & & \\
\hline \multirow{3}{*}{ Özel gereksinimli çocuklara yönelik bilgi } & Var & 36 & 19.08 & 3.60 & & & \\
\hline & Yok & 70 & 19.70 & 3.24 & .89 & 104 & .37 \\
\hline & Toplam & 106 & & & & & \\
\hline \multirow{3}{*}{$\begin{array}{l}\text { Özel gereksinimli çocuklara öğretim sunma } \\
\text { konusundaki güven }\end{array}$} & Var & 36 & 20.69 & 3.72 & & & \\
\hline & Yok & 70 & 19.86 & 3.63 & 1.12 & 104 & .27 \\
\hline & Toplam & 106 & & & & & \\
\hline \multirow{3}{*}{$\begin{array}{l}\text { Etkili öğretim yöntemlerini kullanma ve } \\
\text { uyarlama yapma becerisine yönelik alg1 }\end{array}$} & Var & 36 & 14.03 & 2.98 & & & \\
\hline & Yok & 70 & 13.73 & 2.65 & .53 & 104 & .60 \\
\hline & Toplam & 106 & & & & & \\
\hline \multirow{3}{*}{ Genel } & Var & 36 & 67.92 & 11.16 & & & \\
\hline & Yok & 70 & 66.89 & 9.75 & .49 & 104 & .63 \\
\hline & Toplam & 106 & & & & & \\
\hline
\end{tabular}

Tablo 7’ye göre öğretmen adaylarının kaynaştırmaya yönelik öz-yeterlik algıları, ölçeğin Özel Eğitimle İlgili Yasa ve Süreçlere Yönelik Bilgi $(t(104)=.987, p>.05)$, Özel Gereksinimli Çocuklara Yönelik Bilgi $(t(104)$ $=.893, p>.05)$, Özel Gereksinimli Çocuklara Öğretim Sunma Konusundaki Güven $(t(104)=1.115, p>.05)$ ve 
Etkili Öğretim Yöntemlerini Kullanma ve Uyarlama Yapma Becerisine Yönelik Alg1 $(t(104)=.528, p>.05)$ alt boyutlarında ve ölçek genelinde $(t(104)=.490, p>.05)$ sınıfında özel gereksinimli çocuk bulunma durumu açısından anlamlı bulunmamıştır.

\section{Tartışma}

Nitelikli bir kaynaştırma eğitiminin temel gereklerinden biri bu konuda yeterlilik kazanmış öğretmenlerin görev almasıdır. Öğretmenlerin bu görevi yerine getirebileceklerine dair inançları da yani özel gereksinimli çocukların kaynaştırma uygulamasına ilk olarak katılma firsatını yakaladıkları okul öncesi eğitimde kendilerinden beklenen görevleri yerine getirme konusunda öz-yeterlik algıları da kaynaştırma uygulamalarının başarısı açısından oldukça önemlidir. Okul öncesi öğretmeni adaylarının kaynaştırma eğitimine yönelik öz-yeterlik algılarının ve bu algıları etkileyen faktörlerin belirlenmesiyle hizmet öncesi eğitim programlarının kaynaştırma eğitimi ekseninde yapılandırılması mümkün olabilir. Bu çalışmada okul öncesi öğretmeni adaylarının kaynaştırmaya yönelik öz-yeterlik algı düzeylerini belirlemek ve öğretmen adaylarının kaynaştırmaya yönelik özyeterlik algılarını çeşitli değişkenler açısından incelemek amaçlanmıştır. "Özel Gereksinimli Çocukların Kaynaştırılmasına İlişkin Öğretmen Yeterliği Ölçeği” ile elde edilen sonuçlara göre, okul öncesi öğretmen adaylarının kaynaştırmaya yönelik öz-yeterlik algıları ölçek genelinde "orta” düzeyde bulunmuştur. Adayların kaynaştırma eğitimi öz-yeterlik algı düzeylerinin ölçek genelinde ve ölçeğin alt ölçeklerinde en son mezun olunan okul, daha önce özel gereksinimli bireylerle etkileşimde bulunma durumu, etkileşimin süresi ve öğretmenlik uygulaması yaptığı sınıfta özel gereksinimli çocuk bulunma durumu değişkenleri açısından farklılaşmadığı sonucuna ulaşılmıştır.

Alanyazında okul öncesi öğretmeni adaylarıyla yapılan, ulaşılabilen tek araştırma Walls'in (2007) çalışmasında, öğretmen adaylarının kaynaştırmaya yönelik öz-yeterlik algılarının düzeyine ilişkin veriye ulaşılamamıştır. Yine de Walls'in (2007), aday eğitimi sürecince sadece erken çocukluk genel eğitim programı alan öğretmen adaylarının kaynaştırmaya yönelik öz-yeterliğinin, erken çocukluk özel eğitim programı uygulanan adaylara göre daha düşük olduğu yönündeki bulgusu, okul öncesinde kaynaştırma konusunda öğretmen adaylarının daha yeterli olabilmesi için bu konuda eğitim almasının önemini göstermesi bakımından önemlidir. Okul öncesi öğretmenleri ile yapılmış iki çalışmada da benzer şekilde öğretmenlerin kaynaştırma öz-yeterlik algıları, 'orta' düzeyde bulunmuştur (Çalışkan, 2019; Yaman, 2019). Bu çalışmalardan farklı olarak okul öncesi öğretmenlerinin kaynaştırma öz-yeterlik algıları ‘ortalamanın üstünde' (Özsırkınt1, 2018); 'yeterli' (Sönmez vd., 2018) ve ‘yüksek olasılıkla yapabilirim’ (Özokçu, 2018c) düzeylerinde bulgulanmıştır. Öte yandan Sönmez ve diğerlerinin (2018) çalışmasında, çalışmanın nitel boyutunda görüşme yaptıkları okul öncesi öğretmenlerinin kendilerini yetersiz buldukları sonucuna ulaşılmıştır. Benzer şekilde okul öncesi öğretmenleriyle yapılan diğer çalışmalarda da öğretmenlerin bilgi eksiklerinin olduğunu belirttiği (Altun \& Gülben, 2009; Artan \& UyanıkBalat, 2003; Aydın \& Tuğluk, 2020; Gezer \& Aksoy, 2019; Gök \& Erbaş, 2011; Güleç-Aslan, 2020; Koçyiğit, 2015; Küçük-Doğaroğlu \& Bapoğlu-Dümenci, 2015; Özdemir \& Ahmetoğlu, 2012; Sucuoğlu vd., 2013; Y1kmış vd., 2018; Zabeli, \& Gjelaj, 2020) görülmektedir. Tüm bu sonuçlar, okul öncesi öğretmenlerinin hizmet öncesinde aldıkları eğitimin kaynaştırma uygulamaları konusunda yeterli olmadığına işaret etmektedir. Türkiye'de üniversitelerin okul öncesi öğretmenliği lisans programında zorunlu dersler arasında yalnızca iki kredilik teorik “Özel Eğitim ve Kaynaştırma” dersinin yer aldığı ve de programda özel gereksinimli çocuklar ile ilgili uygulamalı derslerin yer almadığı düşünülecek olursa bu sonucun şaşırtıcı olmadığı söylenebilir. Yine de bu konuda daha doğru bir tartışma yapabilmek için okul öncesi öğretmeni adaylarının kaynaştırmaya yönelik öz-yeterlik algılarını inceleyen daha fazla sayıda çalışma yapılmasına gereksinim vardır.

Farklı branşlarda öğretmen adayları ya da öğretmenlerle farklı ölçme araçları kullanılarak yapılan kaynaştırma öz-yeterliği çalışmalarında katılımcıların kaynaştırmaya yönelik öz-yeterlik alg1 düzeylerinin “yapabilirim” (Toy \& Duru, 2016); yüksek (Yavuz, 2017) ve orta düzeyde (Deniz, 2016; Dolapç1 vd., 2016; VuralBatık \& Fırıncı-Kodaz, 2018) olduğu yönünde sonuçlar elde edilmiştir. Öğretmenin kaynaştırmaya yönelik özyeterlik algısının düzeyi kaynaştırmaya karşı yaklaşımlarını da etkilemektedir (Kiel vd., 2020; Loreman vd., 2013). Düşük yeterlilik duygusuna sahip öğretmenler daha fazla kaygı duymakta ve sınıflarında özel gereksinimli öğrenciyi istememektedir (Soodak \& Podell, 1993). Buna karşın kaynaştırmaya yönelik öz-yeterlik algıları yüksek olan öğretmenlerin, sınıflarında güçlük yaşayan öğrencilerin öğrenmeleri için daha fazla çaba gösterdikleri, en güç öğrenen öğrencilere bile etkili öğretim sunabildikleri görülmektedir (Kaner, 2010). Bandura'nın (1995) da belirttiği gibi öz-yeterlik inancını oluşturan en güçlü etki doğrudan deneyimlerdir ve başarıyla sonuçlanan deneyimler bireyin kendisine güvenini ve öz-yeterlik algılarını arttırmaktadır. Bu bilgiler 1şı̆̆ında okul öncesi öğretmeni adaylarının kaynaştırma ve özel eğitim ile ilgili bilgi, planlama ve uygulama deneyimleri artarsa kaynaştırmaya yönelik öz-yeterlik algılarının da yüksek düzeye ulaşabileceği düşünülmektedir. Bunun da lisans 
eğitiminde yer alan zorunlu ve seçmeli derslerde özel eğitim ve kaynaştırma eğitimi ile ilgili ders sayısının artmasıyla ve derslerde edinilen bilgilerin aday öğretmenlerin staj yaptığı sınıflarda uygulanmasıyla mümkün olabileceği düşünülmektedir.

Araştırmada elde edilen bulgulara göre; okul öncesi öğretmeni adaylarının "Özel Gereksinimli Çocukların Kaynaştırılmasına Yönelik Öğretmen Yeterliği Ölçeği” genelinde ve alt ölçeklerde öz-yeterlik algılarında incelenen dört değişken de anlamlı farklılık yaratmamıştır. En son mezun olunan okul değişkeni açısından bakıldığında katılımcıların çoğunluğunun Anadolu lisesi ve düz liseden mezun olduğu görülmektedir. Meslek liselerinde çocuk gelişimi ve özel eğitim bölümlerinde kaynaştırma ile ilgili bilgilerin verilmesi ve kaynaştırmaya ilişkin uygulama yapma olanaklarının diğer lise türlerine göre daha fazla olmasının öğretmen adaylarının öz-yeterlik alg1 düzeylerini değiştirebileceği düşünülmektedir. Mezun olunan okul açısından anlamlı farklılık olmamasında, meslek lisesi mezunu olan aday öğretmen sayısının az olması bir etken olmuş olabilir. Bunun yanında meslek lisesi mezunu adayların, özel eğitime, özel gereksinimli bireylere yönelik ne kadar bilgi ve deneyim edindiklerine dair bir bilgi de mevcut değildir. Dolayısıyla bu veri meslek liselerinde verilen özel eğitim alanına dair bilgi ve deneyim firsatlarını yeterince sağlayamadığını da gösterebilir. Bu konuda daha fazla çalışmaya gereksinim olduğu görülmektedir.

Alanyazındaki benzer çalışmalarda, özel gereksinimli bireylerle etkileşimde bulunma durumu açısından kaynaştırmaya yönelik öz-yeterlik algılarının farklılaşmasına ilişkin farklı sonuçlar yer almaktadır. Çalışmanın bulgusunu destekleyen benzer bir çalışmada Özokçu (2018c), okul öncesi öğretmenlerinin kaynaştırma öz-yeterlik algılarının özel gereksinimli bireylerle etkileşimde bulunma açısından farklılaşmadığı sonucunu elde etmiştir. Yine Kaner (2010) özel gereksinimli olan ve olmayan öğrencilerin öğretmenlerinin öz-yetkinlik inançlarını incelediği araştırmasında, öğretmenlerin özel gereksinimli olan öğrenciler ile çalışmış olmalarının yetkinlik inançlarında farklılaşmaya neden olmadığı sonucuna ulaşmıştır. Bu çalışmaların bulgularından farklı olarak Loreman ve diğerleri (2013) ise çalışma grubunda okul öncesi öğretmeni adaylarının da olduğu farklı branşlardaki öğretmen adaylarının kaynaştırmaya yönelik öz-yeterliklerini inceledikleri araştırmalarında, aday öğretmenlerin daha önce özel gereksinimli bireylerle etkileşimde bulunma değişkeni ile kaynaştırma öz-yeterliği puanları arasında pozitif anlamlı bir ilişki olduğunu bulmuşlardır. Bu çalışmada okul öncesi öğretmeni adaylarının sadece etkileşimde bulunup bulunmadığı ve süresi sorulmuş, etkileşimin türü, şekli, içeriği ile ilgili veri toplanmamıştır. Dolayısıyla araştırma sonuçlarındaki bu farklılığın nedeni katılımcıların özel gereksinimli bireylerle etkileşimde bulunma şekli ve niteliğinin farklı olması olabilir. Çalışkan'ın (2019) okul öncesi öğretmenleriyle yaptığı çalışmada elde ettiği, daha önce özel gereksinimli çocuklarla çalışmış olmanın anlamlı farklılık yarattığı yönündeki bulgusu da bu durumu örneklemektedir. Etkileşimin biçimi, içeriği, bağlamı gibi etmenler kişilerin özyeterlik algılarını etkileyebilir.

$\mathrm{Bu}$ çalışmada elde edilen özel gereksinimli bireylerle etkileşim süresinin öğretmen adaylarının kaynaştırma öz-yeterlik algılarında farklılık oluşturmadığı yönündeki bulgunun, etkileşimde bulunan adayların yarıdan fazlasının etkileşimde bulunma sürelerinin 4 aydan az olmasından kaynaklanabileceği düşünülmektedir. Her ne kadar özel gereksinimli bireylerle etkileşimin süresi arttıkça öğretmen adaylarının özel gereksinimli çocuklarla ilgili daha olumlu tutumlara ve öz-yeterlik algısına sahip olduğu görülse de (Böddi vd., 2019; Forlin, vd., 2010), etkileşimin süresinden ziyade bu etkileşimin niteliğinin öğretmen adaylarının kaynaştırmaya yönelik öz-yeterlik algılarını daha çok etkileyebileceği de vurgulanmaktadır (Kim, 2012). Bu çalışmada etkileşim süresine dair veriler analiz edilirken, etkileşim süresinin aralıkları çok dar tutulduğunda (ör. 1 aydan az, 2-4 ay gibi) ilgili aralığa giren katılımcı sayısının analiz yapmayı engelleyecek sayıda olduğu görülmüştür. Bu nedenle bu aralıklar birleştirilerek '4 aydan az' ve '4 aydan çok' olacak şekilde iki alt birime ayrılmıştır. Etkileşim süresinin kaynaştırmaya yönelik öz-yeterlik algılarında fark yaratmadığına dair verileri tartışırken bu durumun dikkate alınması gerekmektedir. Ayrıca bu çalışmada etkileşimin amacı, içeriği ve niteliği konusunda bilgi alınmamış olması da bir sınırlılık olarak ele alınabilir. Nitekim Böddi ve diğerlerinin (2019) çalışmasında etkileşimin şekli yarı zamanlı ya da tam zamanlı olarak uygulama yapılmasıdır ve özel gereksinimli çocuklarla etkileşim süreleri buna göre incelenmiştir. Aynı çalışmada etkileşimin olumlu olması da bir değişken olarak ele alınmıştır. Dolayısıyla etkileşimin daha fazla olmasının tek başına bir etken olmadığı, etkileşimlerin olumlu olmasının da bu farkı yaratabileceği düşünülmektedir. Öğretmen adaylarının etkileşimlerinin sınıftaki özel gereksinimli çocuk ile sınırlı kalıp kalmadığı, yaşamlarında özel gereksinimli birey olup olmadığı, nasıl etkileşimde bulundukları, etkileşimin olumlu olup olmadığı gibi etkenlerin de sınanması yararlı olabilir.

Okul öncesi öğretmeni adaylarıyla yapılmış çalışmalar arasında uygulama yaptığı özel gereksinimli çocuk bulunma durumu değişkenine göre anlamlı farklılık göstermediği bulgusunu destekleyen ve desteklemeyen araştırma sonuçları mevcuttur. Kaner (2010) bu çalışmaya benzer şekilde öğretmenlerin sınıflarında özel 
gereksinimli çocuk olmasının yetkinlik inançlarında farklılaşmaya neden olmadığı sonucuna ulaşmıştır. Loreman ve diğerleri (2013) ise aday öğretmenlerin özel gereksinimli çocuklarla staj yapıp yapmamasına göre kaynaştırma öz-yeterliği arasında pozitif anlamlı bir ilişki bulmuştur. Loreman ve diğerlerinin (2013) çalışmasında incelenen değişken ‘özel gereksinimli çocuklarla yapılan stajın' süresi ve niteliğinin burada belirleyici olabileceği hatırda tutulmalıdır. Mevcut çalışmada incelenen 'uygulama sınıfında özel gereksinimli çocuk bulunması' öğretmen adaylarının doğrudan bu çocukla çalıştığı anlamına gelmeyebilir. Bu çalışmaya katılan aday öğretmenlerin, tipik gelişen çocuklarla yaptıkları öğretmenlik uygulaması sırasında özel gereksinimli öğrenciler ile çalışıp çalışmadığı, bu konuda bir mentörlük süreci yaşayıp yaşamadığı gibi pek çok unsur bu sonucu etkilemiş olabilir. Özel gereksinimli çocuklarla çalışma deneyiminin okul öncesi öğretmenlerinin kaynaştırma öz-yeterlik algılarını etkilediği (Çalışkan, 2019; Özokçu, 2018c) de göz önünde bulundurulduğunda öğretmen adaylarının eğitimleri süresince özel gereksinimli çocuklarla çalışma deneyimi kazanmalarının önemi ortaya çıkmaktadır. Okul öncesi öğretmen adaylarının sınıflarında özel gereksinimli çocuk olmasına göre öz-yeterlik algılarında fark olmamasını açıklayabilmek için aynı zamanda öğretmen adaylarının kaynaştırmaya yönelik tutumlarının da incelenmesi gerekebilir. Sınıfında özel gereksinimli çocuk olması gibi dış etkenler bu inancı en başta etkileyemeyebilir. Özel gereksinimli bireyler ile olan yaşantılar, deneyimler sonucunda bireyler bazı tutum ve davranış değişikliğine uğrayabilirler ve olumsuz deneyimler sonucunda belki ilk başta sahip oldukları yüksek düzeyde olan inanç düzeyleri düşebilir. Öğretmen adaylarının özel gereksinimli çocuklarla kaynaştırma uygulamalarında bulunmadan önce ve sonra öz-yeterlik alg1 düzeylerindeki değişimi inceleyen çalışmalar, bu durumu açıklamaya hizmet edebilecek veriler sunabilir.

Çalışmada elde edilen veriler, çalışmanın verilerin toplandığı dönemde bir devlet üniversitesinde okul öncesi öğretmenliğinde öğrenim gören ve çalışmaya katılmaya gönüllü öğretmen adaylarının yanıtlarıyla sınırlıdır. Benzer çalışmaların farklı üniversitelerde öğrenim gören son sınıftaki okul öncesi öğretmen adaylarıyla tekrarlanması önerilebilir. Ayrıca bu çalışmada öğretmen adaylarının kaynaştırmaya yönelik öz-yeterlik algılarının belirlenmesi için bir ölçekten yararlanılması bir sınırlılık olarak ele alınmalıdır. Benzer çalışmanın nicel yöntem yanında nitel araştırma yöntem ve teknikleri de kullanılarak tasarlanması ve uygulanması önerilebilir. Ailesinde özel gereksinimli birey olma durumu, ileride özel eğitim alanında çalışmayı isteme durumu gibi bu çalışmada ele alınmayan başka değişkenler açısından öğretmen adaylarının kaynaştırmaya yönelik öz-yeterlik algıları incelenebilir. Okul öncesi öğretmeni adaylarının genel öğretmenlik öz-yeterlik algıları ile kaynaştırma öz-yeterlik algılarının ilişkisi incelenebilir. Özel gereksinimli bireyler ile etkileşimde bulunma değişkeni ile ilgili olarak, bu etkileşimin niteliğinin kaynaştırma eğitimi öz-yeterlik algısına etkisini inceleyen nitel ve nicel araştırmalar yapılabilir. Okul öncesi öğretmeni adaylarının programlarına kaynaştırmaya yönelik kendilerini daha yeterli hissetmelerini sağlayacak daha fazla sayıda kuramsal ve uygulamalı dersler eklenebilir. Bu dersleri başarma durumları diploma ekine eklenebilir. Resmi ya da özel özel eğitim kurumlarında çalışabilmenin önkoşulu olarak konulabilir.

\section{Yazarların Katkı Düzeyleri}

Çalışmanın birinci yazarı veri toplama, verilerin analizi ve çalışmanın raporlanması görevlerini yürütmüştür. İkinci yazarı ise çalışma konusunu belirleme, araştırma deseni, veri toplama, verilerin analizi ve çalışmanın raporlanması aşamalarında birinci yazara rehberlik eden danışmandır. İkinci yazar ayrıca çalışmanın sorumlu yazarıdır. 


\section{Kaynaklar}

Altun, T., \& Gülben, A. (2009). Okulöncesinde özel gereksinim duyan çocukların eğitimindeki uygulamalar ve karşılaşılan sorunların öğretmen görüşleri açısından değerlendirilmesi [Evaluation of practices and problems in education of pre-school children with special education needs through the views of teachers]. Selçuk Üniversitesi Ahmet Keleşoğlu Eğitim Fakültesi Dergisi, 28, 253-272. https://www.academia.edu/4711543/OKUL\%C3\%96NCES\%C4\%B0NDE \%C3\%96ZEL GEREKS\% C4\%B0N\%C4\%B0M DUYAN \%C3\%87OCUKLARIN E\%C4\%9E\%C4\%B0T\%C4\%B0M\%C4\%B0 NDEK\%C4\%B0_UYGULAMALAR ve KAR\%C5\%9EILA\%C5\%9EILAN_SORUNLARIN \%C $3 \%$ 96\%C4\%9ERETMEN_G\%C3\%96R\%C3\%9C\%C5\%9ELER\%C4\%B0_A\%C3\%87ISINDAN DE\%C4 \%9EERLEND\%C4\%B0R\%C4\%B0LMES\%C4\%B0

Artan, İ., \& Uyanık-Balat, G. (2003). Okul öncesi eğitimcilerinin entegrasyona ilişkin bilgi ve düşüncelerinin incelenmesi [Knowledge and thoughts of the early childhood education teachers on integration]. $\begin{array}{llll}\text { Kastamonu Eğitim } & \text { Dergisi, } & \text { 65-80. }\end{array}$ https://app.trdizin.gov.tr/publication/paper/detail/T0RFeE1qUTA

Aydın, D., \& Tuğluk, M. N. (2020). Okul öncesi öğretmenlerinin öğrenme-öğretme sürecinde öğretimsel uyarlamalara yer verme düzeylerinin belirlenmesi [Determining the level of instructional adaptations of preschool teachers in the learning-teaching process]. Ulakbilge Sosyal Bilimler Dergisi, 8(47), 423-433. https://doi.org/10.7816/ulakbilge-08-47-04

Bakkaloğlu, H., Sucuoğlu, B., \& Yılmaz, B. (2019). Quality of inclusive preschool classrooms: Predictive variables. Education and Science, 44(199), 223-238. https://doi.org/10.15390/EB.2019.7839

Bandura, A. (1977). Self efficacy: Toward a unifying theory of behaioral change. Psychological Review, 84(2), 191-215. https://www.sciencedirect.com/science/article/abs/pii/0146640278900024

Bandura, A. (1995). Exercise of personal and collective efficacy in changing societies. In A. Bandura (Ed.), Selfefficacy in changing societies (pp. 1-45). Cambridge University Press. https://doi.org/10.1017/CBO9780511527692.003

Batu, S. (2010). Factors for the success of early childhood inclusion \& related studies. International Journal of Early Childhood Special Education, 2(1), 57-71. https://www.int-jecse.net/abstract.php?id=40

Böddi, Z., Serfözö, M., Lassú, Z. F., \& Kerekes, V. (2019). Integration-related experience and preparedness from the aspect of Hungarian preschool teacher candidates. International Journal of Early Childhood Special Education, 11(1), 80-91. https://doi.org/10.20489/intjecse.587251

Büyüköztürk, S., Kılıç-Çakmak, E., Akgün, Ö. E., Karadeniz, S., \& Demirel, F. (2011). Bilimsel araştırma yöntemleri [Scientific research methods] (10. bask1). Pegem Akademi.

Camadan, F. (2012). Sınıf öğretmenleri ve sınıf öğretmeni adaylarının kaynaştırma eğitimine ve BEP hazırlamaya ilişkin öz-yeterliklerinin belirlenmesi [Determining primary school teachers' and primary school preservice teachers' self-efficacy beliefs towards integrated education and IEP preparation]. Elektronik Sosyal Bilimler Dergisi, 11(39), 128-138. https://dergipark.org.tr/tr/pub/esosder/issue/6153/82663

Chung, L. C., Marvin, C. A., \& Churchill, S. L. (2005). Teacher factors associated with preschool teacher-child relationships: Teaching efficacy and parent-teacher relationships. Journal of Early Childhood Teacher Education, 25(2), 131-142. https://digitalcommons.unl.edu/specedfacpub/89

Çalışkan, E. (2019). Okul öncesi öğretmenlerinin kaynaştırma eğitimine ilişkin yeterlik inançlarının belirlenmesi [Determination of the qualifications of competences in the pre-school teachers' course training] [Yüksek lisans tezi, Yakın Doğu Üniversitesi]. http://docs.neu.edu.tr/library/6722856675.pdf

Çulhaoğlu-İmrak, H. (2009). Okul öncesi dönemde kaynaştırma eğitimine ilişskin ögrretmen ve ebeveyn tutumları ile kaynaştırma eğitimi uygulanan sinıflarda akran iliş̧kilerinin incelenmesi [Teachers' and parents' attitudes toward inclusion in preschool period and investigation of peer relationship in inclusion classrooms] (Tez Numarası: 230596) [Yüksek lisans tezi, Çukurova Üniversitesi]. Yükseköğretim Kurulu Ulusal Tez Merkezi. 
Deniz, S. (2016). Rehber öğretmen adaylarının özel eğitime yönelik öz-yeterlik algılarının incelenmesi [The survey of pre-service counsellors' self efficacy perceptions towards special education]. Sosyal ve Beşerî Bilimler Araştırmaları Dergisi, 17(38), 154-175. https://dergipark.org.tr/tr/download/article-file/453752

Diken, İ. H. (2006). Preservice teachers' efficacy and opinions toward inclusion of students with mental retardation. Eurasian Journal of Educational Research, 23, 72-81. https://app.trdizin.gov.tr/publication/paper/detail/TmpFNU5USXk

Diken, İ. H., \& Sucuoğlu, B. (1999). Sınıfında zihinsel engelli çocuk bulunan ve bulunmayan sınıf öğretmenlerinin zihin engelli çocukların kaynaştırılmasına yönelik tutumlarının karşılaştırılması [Comparison of attitudes of classroom teachers with and without children with intellectual disability towards integration of children with intellectual disability]. Özel Eğitim Dergisi, 2(3), 25-39. https://doi.org/10.1501/Ozlegt_0000000042

Dolapçı, S., \& Yıldız-Demirtaş, V. (2016). Öğretmen adaylarının öz-yeterlilik algıları ve kaynaştırma eğitimine bakış açıları [Prospective teachers' self-efficacy perceptions and perspectives on inclusive education]. Batı Anadolu Eğitim Bilimleri Dergisi, $\quad 7(13), \quad$ 141-160. https://dergipark.org.tr/tr/pub/baebd/issue/31813/349090

Forlin, C., Cedillo, I. G., Romero-Contreras, S., Fletcher, T., \& Rodríguez-Hernández, H., J. (2010). Inclusion in Mexico: Ensuring supportive attitudes by newly graduated teachers. International Journal of Inclusive Education, 14(7), 723-739. https://doi.org/10.1080/13603111003778569

George, D., \& Mallery, P. (2003). SPSS for Windows step by step: A simple guide and reference. 11.0 update (4th ed.). Allyn \& Bacon.

Gezer, M., S., \& Aksoy, V. (2019). Perceptions of Turkish preschool teachers' about their roles within the context of inclusive education. International Journal of Early Childhood Special Education, 11(1), 31-42. https://doi.org/10.20489/intjecse.583541

Gök, G., \& Erbaş, D. (2011). Okulöncesi eğitimi öğretmenlerinin kaynaştırma eğitimine ilişkin görüşleri ve önerileri [The opinions and suggestions of preschool teachers about inclusion]. International Journal of $\begin{array}{llll}\text { Early Childhood Special } & \text { Education, }\end{array}$ https://dergipark.org.tr/tr/pub/intjecse/issue/8649/107947

Guo, Y., Piasta, S. B., Justice, L. M., \& Kaderavek, J. N. (2010). Relations among preschool teachers' self-efficacy, classroom quality, and children's language and literacy gains. Teaching and Teacher Education, 26(4), 1094-1103. https://doi.org/10.1016/j.tate.2009.11.005

Güleç-Aslan, Y. (2020). Experiences of Turkish preschool teachers for including children with autism spectrum disorders: Challenges faced and methods used. International Journal of Psychology and Educational Studies, 7(2), 37-49. https://dergipark.org.tr/tr/pub/pes/issue/57205/807802

Kaner, S. (2010). Özel gereksinimli olan ve olmayan öğrencilerin öğretmenlerinin öz-yetkinlik inançları [Examining teachers' self-efficacy beliefs of students with and without special needs]. Ankara Üniversitesi Eğitim Bilimleri Fakültesi Dergisi, $193-217$. http://dergiler.ankara.edu.tr/dergiler/40/1342/15557.pdf

Karasar, N. (2006). Bilimsel araştırma yöntemleri [Scientific research methods] (16. baskı). Nobel Yayın Dağıtım.

Kardeş, S., \& Taşkın, N. (2020). Okul öncesi öğretmen adaylarının özel gereksinimli çocuklara yönelik algıları [Preschool teacher candidates' perceptions of special needs children]. Gazi Üniversitesi Gazi Ë̆itim Fakültesi Dergisi, 40(1), 51-73. https://doi.org/10.17152/gefad.658084

Kayhan, N., Şengül, A., \& Piştav-Akmeşe, P. (2012). İlköğretim birinci ve ikinci kademe öğretmen adaylarının kaynaştırmaya ilişkin görüşlerinin incelenmesi [First and second stage of primary teachers candidates investigation on the opinions of mainstreaming]. Ĕgitim ve Öğretim Araştırmaları Dergisi, 1(3), 268-278. http://www.jret.org/FileUpload/ks281142/File/28z.kayhan.pdf

Keleş, O., Dikici-Sığırtmaç, A., \& Dikici, A. (2019). Okul öncesi kaynaştırma sınıfı öğretmenlerinin öz yeterlik (alg1) ölçeği geçerlik güvenirlik çalışması [The study of the reliability and validity of preschool inclusive class teacher self-efficacy (perception) scale]. Gazi Üniversitesi Gazi Eğitim Fakültesi Dergisi, 39(1), 193-210. http://www.gefad.gazi.edu.tr/tr/pub/issue/43993/376966 
Kiel, E., Braun, A., Muckenthaler, M., Heimlich, U., \& Weiss, S. (2020). Self-efficacy of teachers in inclusive classes. How do teachers with different self efficacy beliefs differ in implementing inclusion? European Journal of Special Needs Education, 35(3), 1-17. https://doi.org/10.1080/08856257.2019.1683685

Kilgo. J., \& Gorgiarla, R. (2005). Young children with special needs (2nd ed.). Thomson-Delmar Learning.

Kim, H. J. (2012). The effects of inclusive-classroom experience on early childhood preservice teachers' selfefficacy. Asia-Pacific Journal of Research, 6(1), 161-179. http://www.pecerajournal.com/data/?a=26929

Koçyiğit, S. (2015). Ana sınıflarında kaynaştırma eğitimi uygulamalarına ilişkin öğretmen rehber öğretmen ve ebeveyn görüşleri [The opinions of teachers-counselors and parents about the application of integration in kindergartens]. Uluslararası Türkçe Edebiyat Kültür Eğitim Dergisi, 4(1), 391-415. https://dergipark.org.tr/tr/pub/teke/issue/12853/155846

Kumcağız, H., Demir, Y., \& Karadaş, C. (2017). Okul psikolojik danışmanlarında mesleki tükenmişliğin yordayıcısı olarak özel eğitime ilişkin öz-yeterlik algısı [Perceptions of self-efficacy regarding special education as a predictor of occupational burnout of school counselors]. İönü Üniversitesi Ĕ̈itim Fakültesi Dergisi, 18(3), 312-324. https://dergipark.org.tr/tr/pub/inuefd/issue/31071/341495

Kurniawati, F., Minnaert, A., Mangunsong, F., \& Ahmed, W. (2012). Empirical study on primary school teachers' attitudes towards inclusive education in Jakarta, Indonesia. Procedia-Social and Behavioral Sciences, 69, 1430-1436. https://doi.org/10.1016/j.sbspro.2012.12.082

Kü̧̈ük-Doğaroğlu, T., \& Bapoğlu-Dümenci, S. S. (2015). Sınıflarında kaynaştırma öğrencisi bulunan okul öncesi öğretmenlerin kaynaştırma eğitimi ve erken müdahale hakkındaki görüşlerinin incelenmesi [Examining the opinions of preschool teachers who have inclusion students in their classes about inclusive education and early intervention.]. Hacettepe University Faculty of Health Sciences Journal, 1(2), 460-473. https://dergipark.org.tr/tr/pub/husbfd/issue/7893/103909

Loreman, T., Sharma, U., \& Forlin, C. (2013) Do pre-service teachers feel ready to teach in inclusive classrooms? A four country study of teaching self-efficacy. Australian Journal of Teacher Education, 38(1), 26-44. http://dx.doi.org/10.14221/ajte.2013v38n1.10

Milli Eğitim Bakanlığı. (2013). Millı̂ Eğitim Bakanlığı Temel Eğitim Müdürlüğ̈̈ Okul Öncesi Programı [Ministry of National Education Directorate of Basic Education Preschool Program]. https://sgb.meb.gov.tr/www/icerik_goruntule.php?KNO=361

Meijer, C., \& Foster, S. (1988). The effect of teacher self-efficacy on referral chance. Journal of Special Education, 22(3), 378-385. http://dx.doi.org/10.1177/002246698802200309

Orel, A., Töret. G., \& Zerey, Z. (2004). Sınıf öğretmeni adaylarının kaynaştırmaya yönelik tutumlarının incelenmesi [Investigation of classroom teacher candidates' attitudes for inclusion]. Ankara Üniversitesi Eğitim Bilimleri Fakültesi Özel Eğitim Dergisi, 5(1), 23-33. https://doi.org/10.1501/Ozlegt 0000000076

Özdemir, H., \& Ahmetoğlu, E. (2012). Okul öncesi öğretmenlerinin yaşları ve mesleki deneyimleri açısından kaynaştırma uygulamalarına ilişkin görüşlerin incelenmesi [Examination of pre-school teachers' views on inclusion practices in terms of their ages and professional experiences]. Journal of Educational and $\begin{array}{lllll}\text { Instructional Studies in } & \text { the }\end{array}$ https://arastirmax.com/en/system/files/dergiler/116392/makaleler/2/1/arastirmax-okul-oncesiogretmenlerinin-yaslari-mesleki-deneyimleri-acisindan-kaynastirma-uygulamalarina-iliskingoruslerinin-incelenmesi.pdf

Özokçu, O. (2018a). The relationship between teacher attitude and self-efficacy for inclusive practices in Turkey. Journal of Education and Training Studies, 6(3), 6-12. http://dx.doi.org/10.11114/jets.v6i3.3034

Özokçu, O. (2018b). The relationship between the Turkish pre-service teachers' attitudes and self-efficacy beliefs concerning inclusive. International Online Journal of Educational Sciences, 10(3), 303-324. https://iojes.net/?mod=makale_ing_ozet\&makale_id=42303

Özokçu, O. (2018c). Investigating preschool teachers' self-efficacy in inclusion practices in Turkey. International Education Studies, 11(9), 79-89. https://doi.org/10.5539/ies.v11n9p79 
Özsırkınt1, D. (2018). Okul öncesi ögrretmenleri için kaynaştırma uygulamalarına yönelik pilot bir hizmet içi eğitim programı gelişstirilmesi (Adana ili örneği) [Developing a pilot in-service training programme for preschool teachers to inclusive education applications (In Adana context)]. (Tez Numaras1: 515523) [Yüksek lisans tezi, Çukurova Üniversitesi]. Yükseköğretim Kurulu Ulusal Tez Merkezi.

Rakap, S., Cig, O., \& Parlak-Rakap, A. (2017). Preparing preschool teacher candidates for inclusion: Impact of two special education courses on their perspectives, Research in Special Education Needs, 17(2), 98-109. https://doi.org/10.1111/1471-3802.12116

Savolainen, H., Engelbrecht, P., Nel, M., \& Malinen, O. P. (2012). Understanding teachers' attitudes and selfefficacy in inclusive education: Implications for pre-service and in-service teacher education. European Journal of Special Needs Education, 27(1), 51-68. https://doi.org/10.1080/08856257.2011.613603

Seçer, Z., Çeliköz, N., Sarı, H., Çetin, Ş., \& Büyüktaşkapu, S. (2010). Okul öncesi eğitim kurumlarında çalışan öğretmenlerin kaynaştırma eğitimine yönelik tutumları (Konya ili örneği) [Preschool teachers' attitudes towards inclusive education (Konya case)]. Selçuk Üniversitesi Ahmet Keleşoğlu Eğitim Fakültesi Dergisi, 29(1), 393-406.

Soodak, L., \& Podell, D. (1993). Teacher efficacy and student problem as factors in special education referral. Journal of Special Education, 27, 66-81. https://doi.org/10.1177/002246699302700105

Sönmez, N., Alptekin, S., \& Bıçak, B. (2018). Okul öncesi eğitim öğretmenlerinin kaynaştırma eğitiminde özyeterlik algıları ve hizmetiçi eğitim gereksinimleri: Bir karma yöntem çalı̧̧ması [Self-efficacy perceptions and in-service training needs of preschool teachers in inclusive education: A mixed method study]. Abant İzzet Baysal Üniversitesi Ĕgitim Fakültesi Dergisi, 18(4), 2270-2297. https://dergipark.org.tr/tr/pub/aibuefd/issue/41844/444422

Sönmez, N., Alptekin, S., \& Bıçak, B. (2019). Okul öncesi eğitim öğretmenlerinin kaynaştırma eğitiminde yeterliliklerini artırmaya yönelik geliştirilen hizmetiçi eğitim programının etkisi [The effect of in-service education program developing for improving competences of preschool teachers in the inclusive education]. Iпӧnӥ Üniversitesi Eğitim Fakültesi Dergisi, 20(2), 439-456. https://dergipark.org.tr/tr/download/article-file/811867

Sönmez, N., \& Bıçak, B. (2017). Özel gereksinimli çocukların kaynaştırılmasına yönelik öğretmen yeterliği ölçeğinin Türkçe uyarlaması [An adaptation of the Turkish version of the teacher efficacy for the inclusion of young children with disabilities scale]. International Online Journal of Educational Sciences, $9(1), \quad$ 156-173. $\quad$ https://toad.halileksi.net/sites/default/files/pdf/ozel-gereksinimli-cocuklarinkaynastirilmasina-yonelik-ogretmen-yeterligi-toad.pdf

Sucuoğlu, B. (2006). Yeni ilköğretim programları ve ögretmen yeterlikleri ışığında etkili kaynaştırma uygulamalart [Effective inclusive education practices in the light of new primary education programs and teacher competencies]. Ekinoks Yayınları.

Sucuoğlu, B., \& Akalın, S. (2010). Kaynaştırma sınıflarına alternatif bir bakış: Çevresel davranışsal değerlendirme ile öğretimsel özelliklerin incelenmesi [Eco-behavioral assessment: An alternative method for assessing mainstreamed classrooms in Turkey]. Ankara Üniversitesi Ĕgitim Bilimleri Fakültesi Özel Eğitim Dergisi, 11(1), 19-37. https://doi.org/10.1501/Ozlegt 0000000144

Sucuoğlu, B., Bakkaloğlu, H., İşcen-Karasu, F., Demir, S., \& Akalın, S. (2013). Preschool teachers' knowledge levels about inclusion. Educational Sciences: Theory and Practice, 14(4), 1477-1483. https://files.eric.ed.gov/fulltext/EJ1045044.pdf

Toy, S. N., \& Duru, S. (2016). Sınıf öğretmenlerinin öğretmen öz-yeterlikleri ile kaynaştırma eğitimine ilişkin yeterlik inançlarının karşılaştırılması [The comparison of self-efficacy and inclusive education beliefs of primary school teachers]. Ege Eğitim Dergisi, 17(1), 146-173. https://dergipark.org.tr/tr/download/article-file/225064

Vural-Batık, M., \& Fırıncı-Kodaz, A. (2018). Kurum deneyiminin psikolojik danışman adaylarının özel eğitim özyeterlik algilarına etkisi [The effect of the internship course on counselor trainees' sense of self-efficacy regarding special education]. Ondokuz Mayls Üniversitesi Eğitim Fakültesi Dergisi, 37(1), 209-222. https://dergipark.org.tr/tr/download/article-file/500367 
Walls, S. D. (2007). Early childhood preservice training and perceived teacher efficacy beliefs concerning the inclusion of young children with disabilities [Doctoral dissertation, Auburn University]. https://etd.auburn.edu/handle/10415/1354

Wax, A., \& Dutton, M. (1991, April 4). The relationship between teacher use of cooperative learning and teacher efficacy [Paper presentation]. Annual meeting of American Educational Research Association, Chicago, United States. https://eric.ed.gov/?id=ED332977

Yaman, E. (2019). Okul öncesi öğretmenlerinin kaynaştırma eğitimine ilişkin algılarının bazı demografik özelliklerine göre yordanması [Prediction of preschool teachers perceptions of inclusive education according to some demographic characteristics]. Researcher: Social Science Studies, 7(4), 227-248. https://doi.org/10.29228/rssstudies.39325

Yaşar-Ekici, F. (2017). Okul öncesi öğretmen adayları ile pedagojik formasyon eğitimi alan öğretmen adaylarının öğretmenliğe yönelik öz yeterlik inançlarının karşılaştırılması [Comparison of the self-efficacy beliefs of the preschool teacher candidates and the teacher candidates who studying in pedagogical formation training program toward teaching profession]. Insan ve Toplum Bilimleri Araştırmaları Dergisi, 6(5), 3003-3022. http://www.itobiad.com/tr/download/article-file/386482

Yavuz, M. (2017). Kaynaştırma uygulamalarında çalışan öğretmenlerin kaynaştırma yeterlilik düzeylerini bazı değişkenler açısından incelemesi [Examination of the inclusion competence levels of the teachers working in inclusive practices in terms of some variables]. Uluslararası Eğitim Bilimleri Dergisi, 4(11), 401-415. https://doi.org/10.16991/INESJOURNAL.1445

Yaylacı, Z., \& Aksoy, B. (2016). Sosyal bilgiler öğretmenlerinin kaynaştırma eğitimindeki yeterlilikleri [Competence of social science teachers in inclusive education]. Uluslararası Türk Eğitim Bilimleri Dergisi, 2016(6), 19-40. https://dergipark.org.tr/tr/pub/goputeb/issue/34311/379157

Yıkmış, A., Aktaş, B., Karabulut, A. H., \& Terzioğlu, N. K. (2018). Okul öncesi öğretmenlerinin kaynaştırma sürecinde yaptıkları çalışmalar [Pre-school teachers' studies in the process of inclusion]. Abant İzet Baysal Üniversitesi Eğitim Fakültesi Dergisi. 1843), https://dergipark.org.tr/tr/download/article-file/555051

Yıkmış, A., \& Bahar, M. (2002). Kaynaştırma sınıflarında çalışan öğretmenlerin kaynaştırma becerilerini gerçekleştirme durumlarının saptanması [Determining the realization of inclusion skills of teachers working in inclusive classrooms]. Abant İzzet Baysal Üniversitesi Ĕ̈itim Fakültesi Dergisi, 2(1), 85-95. https://dergipark.org.tr/tr/pub/aibuefd/issue/1508/18290

Yükseköğretim Kurulu. (2018). Okul öncesi öğretmenliği lisans programı [Preschool teacher degree program]. https://www.yok.gov.tr/Documents/Kurumsal/egitim_ogretim_dairesi/Yeni-Ogretmen-YetistirmeLisans-Programlari/Okul_Oncesi_Ogretmenligi_Lisans_Programi.pdf

Zabeli, N., \& Gjelaj, M. (2020). Preschool teacher's awareness, attitudes and challenges towards inclusive early childhood education: A qualitative study. Cogent Education, 7(1), 1-17. https://doi.org/10.1080/2331186X.2020.1791560 


\section{Ankara University Faculty of Educational Sciences Journal of Special Education}

2021, 22(4), 921-943
RESEARCH

Recieved Date: 25.09 .20

Accepted Date: 04.03.21

OnlineFirst: 23.03 .21

\title{
Investigation of the Self-Efficacy Perceptions of the Preschool Teacher Candidates on Inclusive Education*
}

\author{
Serpil Başpınar iD 1
}

\author{
Nesrin Sönmez (D)2
}

\begin{abstract}
Introduction: The quality of inclusive education practices in preschool period is directly related to the competencies of the teachers who carry out these practices. The aim of this study is to determine the self-efficacy perception levels of the preschool teacher candidates in inclusive education and to analyse the self-efficacy perceptions of the teacher candidates on inclusive education in terms of the variables including their latest graduation level, the state of interacting with individuals with special needs before, the duration of the interaction and having a child with special needs in the classroom.
\end{abstract}

Method: The study group consisted of 107 students studying at department of pre-school education. Demographic information form and "The Teacher Efficacy for the Inclusion of Young Children with Disabilities" scale were used as data collection tools.

Findings: The level of the self-efficacy perceptions of the teacher candidates in inclusive education had a medium level. There was no significant difference in terms of the variables examined.

Discussion: Preschool teacher candidates' perceptions of self-efficacy towards inclusion was not at the desired level, indicating that their knowledge and experiences about inclusion and special education were not sufficiently provided in pre-service education. It is thought that further studies need to determine possible factors affecting self-efficacy perception. The suggestions include using the qualitative method, examining the relationship between pre-service teachers' perceptions of general teaching and their self-efficacy towards inclusion.

Keywords: Preschool education, teacher candidate, inclusion, self-efficacy perception, special education.

To cite: Başpınar, S., \& Sönmez, N. (2021). Investigation the self-efficacy perceptions of the preschool teacher candidates on inclusive education. Ankara University Faculty of Educational Sciences Journal of Special Education, 22(4), 921-943. https://doi.org/10.21565/ozelegitimdergisi.799776

\footnotetext{
*This study was produced from the first author's master thesis accepted at Akdeniz University Institute of Educational Sciences. ${ }^{1}$ Specialist, Kumluca Sarıcasu Special Education Vocational School, E-mail: serpilbspnr@ gmail.com, https://orcid.org/00000002-1622-117X

${ }^{2}$ Corresponded Author: Assist. Prof., Akdeniz University, E-mail: ndilersonmez@gmail.com, https://orcid.org/0000-0002$\underline{2497-2336}$
} 


\section{Introduction}

Preschool education is necessary and important for children with special needs (CSNs) as well as for typically developing children (Ministry of National Education, 2013). When CSNs start to receive education with their peers as early as possible, the importance of inclusive education in preschool education increases even more, since the expected difference between them and their peers will be less in the following years (Batu, 2010). It is the responsibility of teachers to meet the needs of CSNs in the classroom and to ensure their social acceptance (Aydın \& Tuğluk, 2020). The teacher is a unifying force in the integration of CSNs, in creating a positive classroom environment and in the participation of families in the process (Sucuoğlu et al., 2013). In addition, the willingness of teachers in inclusion practices and their acceptance of CSNs positively affect the success of inclusion practices (Kayhan et al., 2012; Rakap et al., 2017, Seçer et al., 2010). Teachers' views on inclusion, their education on inclusion, and their relationships with their students are variables that predict the overall quality of inclusive preschool classes (Bakkaloğlu et al., 2019). Therefore, it is very important in terms of the success of inclusion practices of teachers working in preschool education institutions to fulfill the duties expected from them (Kurniawati et al., 2012; Özdemir \& Ahmetoğlu, 2012).

When the literature is examined, it is seen that preschool education teachers' knowledge level towards inclusive education is not sufficient (Altun \& Gülben, 2009; Artan \& Uyanık-Balat, 2003; Aydın \& Tuğluk, 2020; Gezer \& Aksoy, 2019; Gök \& Erbaş, 2011; Güleç-Aslan, 2020; Koçyiğit, 2015; Küçük-Doğaroğlu \& BapoğluDümenci, 2015; Özdemir \& Ahmetoğlu, 2012; Sucuoğlu et al., 2013; Yıkmış et al., 2018; Zabeli \& Gjelaj, 2020). Educators lack knowledge about effective intervention in problem behaviors experienced by children, preparing an individual education plan (IEP), adapting activities and educational environment, types and issues of disability (Çulhaoğlu-İmrak, 2009; Gök \& Erbaş, 2011). Yıkmış and Bahar (2002) found that the classroom and branch teachers working in inclusive class were insufficient in determining educational goals without the help of experts, conducting facilitating and supportive activities, organizing and implementing the instruction, enabling CSNs to communicate with students without special needs, and allocating time to assessment tools and processes.

Difficulties faced by teachers in the inclusive education process bring negative attitudes and make it difficult to implement the inclusion programs in a qualified and efficient manner. These difficulties experienced by teachers negatively affect their perspectives on inclusive education, causing children to feel inadequate as they do not know how to approach and manage the education process (Güleç-Aslan, 2020; Sönmez et al., 2018). Difficulties faced by teachers in the inclusive education process bring negative attitudes and make it difficult to implement the inclusion programs in a qualified and efficient manner (Diken \& Sucuoğlu, 1999; Gök \& Erbaş, 2011; Orel et al., 2004; Zabeli \& Gjelaj, 2020), which also makes them feel inadequate (Güleç-Aslan, 2020; Sönmez et al., 2018).

Teachers' perceptions of self-efficacy in inclusive education affect their attitudes towards inclusion (Diken, 2006; Dolapçı \& Yıldı-Demirtaş, 2016; Kiel et al., 2020; Savolainen et al., 2012; Soodak \& Podell; 1993; Toy \& Duru; 2016). Teachers with high self-efficacy are less likely to direct their students who are suspicious of special education to special education (Meijer \& Foster, 1988), and prospective teachers who do not see themselves as competent do not wish to have CSNs in their class (Kardeş \& Taşkın, 2020). These results show the importance of teacher's self-efficacy perception in inclusion practices.

There are many studies examining the self-efficacy perceptions of teachers / pre-service teachers from different fields in inclusive education (Camadan, 2012; Deniz, 2016; Forlin et al., 2010; Kumcağız et al., 2017; Loreman et al., 2013; Özokçu, 2018a, 2018b; Savolainen et al., 2012; Toy \& Duru, 2016; Vural-Batık \& Fırınc1Kodaz, 2018; Yavuz, 2017; Yaylac1 \& Aksoy, 2016). There are many studies conducted with teachers, but only one study (Walls, 2007) with pre-service teachers was found. Among the studies conducted with preschool teachers, Sönmez et al. (2018) determined that the self-efficacy perceptions of preschool teachers were at 'sufficient' level. However, in the qualitative aspect of the same study, the teachers stated that they were insufficient in inclusive education and they needed in-service training. Çalışkan (2019) stated that preschool education teachers' self-efficacy perceptions in inclusion were at the level of 'high probability', Özokçu (2018c) determined it as 'with high probability'. Yaman (2019) found the competencies of knowing and using the methods and techniques applied by teachers in inclusive education and the competencies of knowing and applying the principles of inclusion education at a 'medium' level.

In the preschool period, when development and learning are the fastest, inclusive education and teachers' competencies in inclusion are important in order to diagnose the CSNs early and to maximize their potential by making early intervention. Research results reveal that teachers' self-efficacy perception level directly affects their 
success in and outside the classroom and shapes the learning-teaching processes. In this study, it was aimed to determine the preschool teacher candidates' self-efficacy perceptions about inclusive education and to examine pre-service teachers' self-efficacy perception levels in terms of different variables. For this purpose, answers to the following questions were sought:

1. What is the level of self-efficacy perception of preschool teacher candidates in inclusive education in the overall and subscales of Teacher Efficacy for the Inclusion of Young Children with Disabilities scale?

2. Do the self-efficacy perception levels of preschool teacher candidates in the overall and subscales of Teacher Efficacy for the Inclusion of Young Children with Disabilities scale differ according to

2.1. The latest graduation level,

2.2. Interacting with individuals with special needs before,

2.3. Interaction time with individuals with special needs and

2.4. Having a child with special needs in the classroom during the teaching practice?

\section{Method}

\section{Research Design, Study Group and Data Collection Tools}

This study utilized the survey model which aimed to identifty the self-efficacy perception levels of the preschool teacher candidates in inclusive education. The study group consisted of 107 pre-school education teacher candidates who were studying in the preschool education teaching department of a state university in the 20162017 academic year. These candidates participated voluntarily in the study. 85\% of the participants are women. Equally, the participants (29.9\%) were high school and Anatolian high school graduates, while a low percentage of them held associate (4.7\%) and undergraduate degrees (0.9\%). More than half of the participants $(58.9 \%)$ stated that they interacted with individuals with special needs (ISNs). It was observed that the interaction times of $65 \%$ of those who interacted with ISNs were shorter than four months. Considering the status of having an inclusion student in the classroom where she taught, it was seen that $66.4 \%$ of the participants were not CSNs in their class. The data were obtained using the Teacher Candidate Information Form for obtaining demographic information created by the researchers and the "The Teacher Efficacy for the Inclusion of Young Children with Disabilities (TEIYCD)" scale adapted into Turkish by Sönmez and Bıçak (2017).

\section{Data Collection and Analysis}

The research data were collected in the spring semester of the 2016-2017 academic year. During data collection, the researchers were careful not to violate any ethics rules. In order to collect the data, ${ }^{\text {th }}$ grade teacher candidates studying at the department of preschool education were interviewed. In a classroom in the Faculty of Education, students were met on a predetermined day and time. Preliminary information was given to the participants about the research. It was especially stated that no identification information should be written on the forms. In addition, they were informed about filling the forms in a sincere and complete manner.

SPSS 13.0 was used in data analysis. For the analysis of the research data, when the analyzed variable had two subgroups, the unrelated samples t test or (its non-parametric equivalent) Mann Whitney U Test was used. When the analyzed variable has more than two subgroups, for unrelated samples ANOVA or (its non-parametric equivalent) Kruskal Wallis H-Test was used.

\section{Results}

The level of pre-school teacher candidates' self-efficacy perceptions in inclusive education was determined. As the scores obtained from the TEIYD scale were examined, preschool teacher candidates' selfefficacy perceptions about inclusive education were at a 'medium' level. It was also examined whether the selfefficacy perceptions of teacher candidates differed in terms of the variables. The results obtained for the four variables examined were as follows:

\section{Latest Graduation Level}

According to the results of the Kruskal Wallis H-Test, it was found that the pre-service teachers did not differ significantly in terms of the latest graduation level in the sections of the scale (Knowledge about the Laws and Processes Relating to Special Education $(H(3)=.245, p>.05)$, Knowledge about Children with Disabilities 
$(H(3)=2.134, p>.05)$, Confidence Related to Teaching Children with Disabilities $(H(3)=1.359, p>.05)$, Perception of Skill in Using and Adapting Effective Teaching Methods $(H(3)=1.482, p>.05)$. The pre-service teachers' self-efficacy perceptions did not make a significant difference across the scale in terms of the latest graduation level $(H(3)=1.750, p>.05)$.

\section{Interacting with Individuals with Special Needs Before}

According to the results of unrelated samples t test, it was found that teacher candidates' self-efficacy perceptions in the sections of the scale did not differ significantly in terms of interacting with ISNs before (Knowledge about the Laws and Processes Relating to Special Education $(t(104)=1.279, p>.05)$, Knowledge about Children with Disabilities $(t(104)=.181, p>.05)$, Confidence Relating to Teaching Children with Disabilities $(t(104)=1.139, p>.05)$, Perception of Skill in Using and Adapting Effective Teaching Methods $(t(104)=.623, p>.05)$. Pre-service teachers' perceptions of inclusive education self-efficacy did not make a significant difference across the scale in terms of interacting with ISNs $(t(104)=.951, p>.05)$.

\section{Interaction Time with Individuals with Special Needs}

The Mann Whitney U Test was applied to test whether pre-service teachers' self-efficacy perceptions differed in terms of the interaction time with ISNs. It was concluded that teacher candidates' self-efficacy perceptions in inclusive education did not differ significantly in the sections of the scale in terms of the interaction time with ISNs (Knowledge about the Laws and Processes Relating to Special Education $(U=369.00, p>.05)$, Knowledge about Children with Disabilities $(U=324.50, p>.05)$, Confidence Relating to Teaching Children with Disabilities $(U=347.00, p>.05)$, Perception of Skill in Using and Adapting Effective Teaching Methods $(U=$ $352.50, p>.05)$. Pre-service teachers' perceptions of inclusive education self-efficacy did not make a significant difference across the scale in terms of the interaction time with ISNs $(U=475.00, p>.05)$.

\section{Having a Child with Special Needs in the Classroom During the Teaching Practice}

In order to test whether the pre-service teachers' self-efficacy perceptions differed in terms of having an inclusive child in their classroom, unrelated samples t-test was conducted. Accordingly, pre-service teachers' selfefficacy perceptions in inclusion were not found to be significant in terms of having a child with special needs in the classroom in the sections of the scale (Knowledge about the Laws and Processes Relating to Special Education $(t(104)=.987, p>.05)$, Knowledge about Children with Disabilities $(t(104)=.893, p>.05)$, Confidence Relating to Teaching Children with Disabilities $(t(104)=1.115, p>.05)$, Perception of Skill in Using and Adapting Effective Teaching Methods $(t(104)=.528, p>.05)$. Self-efficacy perceptions of pre-service teachers across the scale were not found to be significant in terms of having a child with special needs in the classroom $(t(104)=.490$, $p>.05)$.

\section{Discussion}

According to the results obtained with the The Teacher Efficacy for the Inclusion of Young Children with Disabilities (TEIYCD) scale, preschool teacher candidates' perceptions of self-efficacy in inclusive education were found to be at a "medium" level throughout the scale. It was concluded that the self-efficacy perception levels of the candidates did not differ across the scale and in the subtests of the scale in terms of the variables examined in the previous section. In the study of Walls (2007), the only research that was conducted with preschool education teacher candidates in the literature, data on the level of inclusive education self-efficacy perceptions of pre-service teachers could not be reached. Nevertheless, Walls (2007) found that the pre-service teachers who only received early childhood general education program during the preschool education process had lower inclusive education self-efficacy compared to the candidates who received early childhood special education program. This data is important in terms of showing the importance of pre-service teacher education on this subject. Similarly, in two studies conducted with preschool education teachers, inclusive self-efficacy perceptions of teachers were found to be at 'moderate' level (Çalışkan, 2019; Yaman, 2019). Unlike these studies, inclusive education self-efficacy perceptions of preschool teachers were found to be at the levels of "above average" (Özsırkınt1, 2018), 'sufficient' (Sönmez et al., 2018), and 'with high probability' (Özokçu, 2018c). On the other hand, in the study of Sönmez et al. (2018), it was concluded that preschool education teachers whom they interviewed in the qualitative aspect of the study found themselves inadequate. Similarly, in other studies conducted with preschool education teachers, teachers stated that they had lack of knowledge (Altun \& Gülben, 2009; Artan \& Uyanık-Balat, 2003; Aydın \& Tuğluk, 2020; Gezer \& Aksoy, 2019; Gök \& Erbaş, 2011; Güleç-Aslan, 2020; Koçyiğit, 2015; Küçük-Doğaroğlu \& Bapoğlu-Dümenci, 2015; Özdemir \& Ahmetoğlu, 2012; Sucuoğlu et al., 2013; Yıkmış et al., 2018; Zabeli \& Gjelaj, 2020). All these results may indicate that preschool education teachers' pre-service education is not 
sufficient in inclusive education. More studies are needed to examine pre-school teacher candidates' self-efficacy in inclusive education in order to have a more accurate discussion on this issue.

In inclusive self-efficacy studies conducted with pre-service teachers or teachers in different branches in the literature, using different measurement tools, the levels of inclusive self-efficacy perception of participants were found at the levels of 'I can' (Toy \& Duru, 2016); 'high' (Yavuz, 2017), and 'medium' (Deniz, 2016; Dolapç1 \& Yıldız-Demirtaş, 2016; Vural-Batık \& Firınc1-Kodaz, 2018). The low or high perception of teachers' selfefficacy in inclusion practices also affects their approach to inclusion practices (Kiel et al., 2020; Loreman et al., 2013). Teachers with a low sense of competence worry more and do not want ISNs in their classrooms (Soodak \& Podell, 1993). On the other hand, it has been observed that teachers with strong self-efficacy perceptions spend more effort to students with learning difficulties in their classes (Kaner, 2010). As stated by Bandura (1995), it is known that the most powerful effect that creates self-efficacy belief is direct experiences, and successful experiences increase self-efficacy perceptions by motivating the individual's self-confidence and future success. In the light of this information, it is thought that if preschool teacher candidates' knowledge, planning and application experiences about inclusive education and special education increase, their self-efficacy perceptions about inclusive education may reach a high level. It is thought that this will be possible by increasing the number of courses related to special education and inclusive education in compulsory and elective courses in undergraduate education and by applying the knowledge gained in the courses in the classes where prospective teachers do internships.

In terms of the latest graduation level, it is seen that most of the participants graduated from Anatolian high school and regular high school. It is thought that providing information about inclusive education in child development and special education departments in vocational high schools and having more opportunities to practice inclusive education compared to other high school types may change the self-efficacy perception levels of teacher candidates. The low number of prospective teachers who graduated from vocational high schools may have been a factor in the lack of significant difference in terms of the graduation. In addition, there is no information about how much knowledge and experience vocational high school graduate candidates have acquired for special education and ISNs. Therefore, this data may also show that they do not provide sufficient knowledge and experience opportunities in the field of special education provided in vocational high schools. It seems that more studies are needed on this subject.

In similar studies in the literature, there are different results regarding the differentiation of self-efficacy perceptions towards inclusive education in terms of interacting with individuals with special needs before. In a similar study supporting the findings of the study, Özokçu (2018c) concluded that preschool teachers' self-efficacy perceptions on inclusion did not differ in terms of interacting with ISNS before. Again, Kaner (2010), in her research investigating the self-efficacy beliefs of teachers of students with and without special needs, concluded that teachers' working with students with special needs did not cause any difference in self-efficacy beliefs. Different from the findings of these studies, Loreman et al. (2013) examined the self-efficacy of pre-service teachers in different branches in the study group including preschool teacher candidates. They found a positive significant relationship between the pre-service teachers' interactions with ISNs previously and their self-efficacy scores in inclusive education. In our study, only the interaction status of preschool education teacher candidates was taken into consideration, and no data were collected on the type and form of this interaction. Therefore, the reason for this difference in these results may be that the participants interacted with ISNs and their quality was different. The finding that Çalıskan (2019) obtained in his study with preschool education teachers that having worked with CSNs before made a significant difference also exemplifies this situation. Factors such as the form, content, duration, and context of the interaction can affect people's self-efficacy perceptions.

The finding that the interaction time with individuals with special needs does not make a difference in pre-service teachers' self-efficacy perceptions in inclusive education is thought to be due to the fact that the interaction time of more than half of the candidates was less than 4 months. Although it is observed that as the time of interaction with ISNs increases, teacher candidates have more positive attitudes and self-efficacy perceptions about CSNs (Böddi et al., 2019; Forlin et al., 2010), it is also emphasized that rather than the time of the interaction, the quality of the interaction may affect pre-service teachers' perceptions of self-efficacy in inclusion more (Kim, 2012). In this study, while analyzing the data on the duration of the interaction, it was seen that when the intervals of the interaction time were kept very narrow (e.g. less than 1 month, 2-4 months), the number of participants in the relevant range was sufficient to prevent analysis. For this reason, these intervals were combined and divided into two sub-units as "less than 4 months" and "more than 4 months". This should be taken into account while showing that interaction time did not make a difference in inclusive self-efficacy perceptions. In addition, the lack of information about the purpose, content 
and nature of the interaction can be considered as a limitation in this study. As a matter of fact, in the study of Böddi et al. (2019), the nature of the interaction is the application on a part-time or full-time basis, and the duration of interaction with children with special needs was examined accordingly. In the same study, the positive interaction was considered as a variable. Therefore, it is thought that having more interaction is not a single factor, and that positive interactions can also make this difference. It may be useful to test factors such as whether teacher candidates' interactions are limited to the student with special needs in the classroom, whether there are ISNs in their lives, how they interact, and whether the interaction is positive or not.

Among the studies conducted with preschool education teacher candidates, there are research results that support and do not support the finding that it does not differ significantly according to the variable of having $a$ child with special needs in the classroom. Similar to this study, Kaner (2010) concluded that having inclusive children in teachers' classrooms did not cause any difference in self-efficacy beliefs. Loreman et al. (2013) found a positive significant relationship between inclusive education self-efficacy according to whether or not prospective teachers did internships with CSNs. It should be kept in mind that the duration and quality of the variable "internship with children with special needs" examined in the study of Loreman et al. (2013) may be decisive here. The "presence of a child with special needs in the practice class" examined in the present study may not mean that the teacher candidates directly work with this child. In this study, many factors such as whether the prospective teachers worked with the CSNs during their teaching practice with typically developing children, whether they had a mentoring process on this issue, may have affected this result. Considering that the experience of working with CSNs affects the perceptions of inclusive self-efficacy of preschool education teachers (Çalışkan, 2019; Özokçu, 2018c), the importance of teacher candidates gaining experience of working with CSNs during their education becomes evident. In order to explain that there is no difference in preschool education teachers 'self-efficacy perceptions compared to having inclusive children in their classrooms, it may also be necessary to examine pre-service teachers' attitudes towards inclusion. External factors, such as the presence of an inclusive child in the class, may not affect this belief in the first place. As a result of such experiences, individuals may undergo some attitude and behavior changes, and as a result of negative experiences, perhaps their high level of beliefs may decrease. Studies that examine the change in pre-service teachers' self-efficacy perception levels before and after inclusive education practice with CSNs can provide data that can serve to explain this situation.

The data in the study are limited to the responses of the teacher candidates who were enrolled in preschool education at a state university. It may be suggested to repeat similar studies with senior pre-school education teacher candidates studying at different universities. In addition, the use of the TEIYD scale to determine preservice teachers' perceptions of self-efficacy in inclusion should be considered as a limitation in this study. It may be suggested that similar studies should be designed and implemented using qualitative research methods and techniques as well as quantitative methods. The pre-service teachers' perceptions of self-efficacy in inclusion can be examined in terms of other variables that are not addressed in this study, such as the status of being an ISNs in their family, the lessons learned in the field of special education, and the status of wanting to work in the field of special education in the future. The relationship between pre-school teacher candidates' perceptions of general teaching self-efficacy and inclusive self-efficacy can be examined. Regarding the variable of interacting with ISNs, qualitative and quantitative studies can be conducted that examine the effect of the quality of this interaction on the perception of inclusive education self-efficacy. More theoretical and practical courses can be added to preschool education teacher candidates to make them feel more competent in inclusive education. Success of these courses can be added to the diploma supplement. It can be set as a precondition for working in official or private special education institutions.

\section{Author's Contributions}

The first author of the study carried out the tasks of collecting data, analyzing the data and reporting the study. The second author is the consultant who guided the first author in determining the subject of the study, research design, data collection, data analysis and reporting of the study. The second author is also the responsible author of the study. 